\title{
Seasonal leaf dynamics for tropical evergreen forests in a process-based global ecosystem model
}

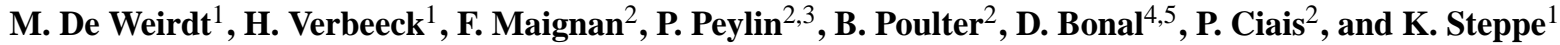 \\ ${ }^{1}$ Laboratory of Plant Ecology, Department of Applied Ecology and Environmental Biology, \\ Faculty of Bioscience Engineering, Ghent University, Coupure Links 653, 9000 Ghent, Belgium \\ ${ }^{2}$ Laboratory of Climate Sciences and the Environment (LSCE), Joint Unit of CEA-CNRS, L'Orme des Merisiers, \\ 91191 Gif-sur-Yvette, France \\ ${ }^{3}$ Laboratory of Biogéochimie et Ecologie des Milieux Continentaux (BioEMCO), Thiverval-Grignon, 78850, France \\ ${ }^{4}$ INRA Kourou, UMR745 Ecologie des Forêts de Guyane, Campus Agronomique, 97387 Kourou Cedex, French Guiana \\ ${ }^{5}$ INRA Nancy, UMR INRA-UHP1137 Ecologie et Ecophysiologie Forestière, 54280 Champenoux, France
}

Correspondence to: M. De Weirdt (marjolein.deweirdt@ugent.be)

Received: 23 December 2011 - Published in Geosci. Model Dev. Discuss.: 24 February 2012

Revised: 7 August 2012 - Accepted: 9 August 2012 - Published: 6 September 2012

\begin{abstract}
The influence of seasonal phenology on canopy photosynthesis in tropical evergreen forests remains poorly understood, and its representation in global ecosystem models is highly simplified, typically with no seasonal variation of canopy leaf properties taken into account. Including seasonal variation in leaf age and photosynthetic capacity could improve the correspondence of global vegetation model outputs with the wet-dry season $\mathrm{CO}_{2}$ patterns measured at flux tower sites in these forests. We introduced a leaf litterfall dynamics scheme in the global terrestrial ecosystem model ORCHIDEE based on seasonal variations in net primary production (NPP), resulting in higher leaf turnover in periods of high productivity. The modifications in the leaf litterfall scheme induce seasonal variation in leaf age distribution and photosynthetic capacity. We evaluated the results of the modification against seasonal patterns of three long-term in-situ leaf litterfall datasets of evergreen tropical forests in Panama, French Guiana and Brazil. In addition, we evaluated the impact of the model improvements on simulated latent heat (LE) and gross primary productivity (GPP) fluxes for the flux tower sites Guyaflux (French Guiana) and Tapajós (km 67, Brazil). The results show that the introduced seasonal leaf litterfall corresponds well with field inventory leaf litter data and times with its seasonality. Although the simulated litterfall improved substantially by the model modifications, the impact on the modelled fluxes remained limited. The seasonal pattern of GPP improved clearly for the Guyaflux site,
\end{abstract}

but no significant improvement was obtained for the Tapajós site. The seasonal pattern of the modelled latent heat fluxes was hardly changed and remained consistent with the observed fluxes. We conclude that we introduced a realistic and generic litterfall dynamics scheme, but that other processes need to be improved in the model to achieve better simulations of GPP seasonal patterns for tropical evergreen forests.

\section{Introduction}

As a major component of the global terrestrial carbon cycle, intact tropical forests contribute a significant fraction of the global carbon sink (Pan et al., 2011) and may also be vulnerable to drought in the future, causing a positive feedback on climate change (Prentice and Lloyd, 1998; Tian et al., 1998; Cox et al., 2000). Tropical forests are estimated to store $55 \%$ of the global forest carbon stock (Pan et al., 2011) and to account for $34 \%$ of global terrestrial photosynthesis (GPP) according to Beer et al. (2010). It is still uncertain whether wet tropical forests are a global carbon sink (Stephens et al., 2007; Lewis et al., 2004; Phillips et al., 1998; Chambers and Silver, 2004; Luyssaert et al., 2008; Cramer et al., 2004; Pan et al., 2011; Gloor et al., 2009; Lloyd and Farquhar, 2008), but they could turn into a source of $\mathrm{CO}_{2}$ for the atmosphere due to drought-induced dieback (Cox et al., 
2004; Malhi et al., 2008, 2009b) or increased disturbances in association with global environmental changes (Golding and Betts, 2008; Phillips et al., 2009; Poulter et al., 2010).

Global vegetation models have however difficulties in reproducing the seasonality of $\mathrm{CO}_{2}$ fluxes for tropical evergreen forests (Baker et al., 2008; Saleska et al., 2003; Poulter et al., 2009). Using ORCHIDEE (Krinner et al., 2005), a process-based carbon-water-energy model, Verbeeck et al. (2011) showed that the seasonal cycle of net $\mathrm{CO}_{2}$ exchange (NEE) and latent heat flux could be brought in agreement with eddy covariance observations from two sites in the drought-prone forests of the Amazon, by increasing the soil rooting depth parameter in the model from $1.5 \mathrm{~m}$ to $10 \mathrm{~m}$, hereby reducing modelled drought stress sensitivity and maintaining high transpiration during the dry season in the model. The model calibration study of Verbeeck et al. (2011) also highlighted that phenological processes for tropical evergreen forests were incorrect in the ORCHIDEE model structure. In particular, the seasonality required for the optimized parameters to match the flux observations suggested that a module that simulates leaf renewal would be needed in the model before or at the onset of the dry season. The bias of seasonal fluxes found in the ORCHIDEE model is common to other process-based ecosystem models (Saleska et al., 2003).

The representation of seasonal variability in leaf phenology in most vegetation models is currently highly simplified. Unlike vegetation in temperate or dry regions, tropical evergreen forests are not synchronised with each other in a community-wide phenology (Chave et al., 2010) and global vegetation models thus assume no seasonality in phenology for tropical evergreen canopies (Botta et al., 2000; Poulter et al., 2009; Maignan et al., 2011). It is however important to model leaf turnover correctly, because this process not only affects GPP but also drives litterfall, litter decomposition and biogeochemical cycling of carbon and nutrients.

Tropical trees show a wide range of variation in leaf phenotypic behaviour between and within species, individuals, locations and years (Malhado et al., 2009). Nevertheless, high rates of leaf litterfall towards the end of the wet season and onset of dry season are well documented in various rainforests sites (Bradley et al., 2011; Doughty and Goulden, 2008; Goulden et al., 2004; Borchert, 1998; Wright and Cornejo, 1990; Nepstad et al., 2002; Chave et al., 2010). Table 1 reports leaf litterfall measurements from 16 tropical evergreen forests in the world that show distinct seasonal dynamics. Chave et al. (2010) reported a significant positive relationship between rainfall seasonality and litterfall seasonality for these and various other sites in Brazil, Peru, Ecuador, Colombia and Panama. In Dimonika, DR Congo (Schwartz and Tondo, 1988), the litter peak times with increased irradiance during the rainy season instead of during the dry season which coincides with the presence of a thick, rainless, fog layer formed by the presence of the cold Benguela Stream. Data from the locations in Table 1 all show increased litterfall with increased radiation, except for Braga-Supay in Peru (Nebel et al., 2001), which shows a litterfall peak in the rainy season during the flooding period. A canopy response to increased light availability over the Amazon is also suggested by satellite vegetation greenness index measurements that suggest a photosynthetic or phenological positive and anticipatory response to elevated light levels during the dry season (Huete et al., 2006; Myneni et al., 2007; Xiao et al., 2005). Yet, the significance of satellite greening during dry periods is a controversial subject (Myneni et al., 2007; Poulter et al., 2009; Samanta et al., 2010a, b; Caldararu et al., 2011).

This study aims to incorporate the seasonality of leaf litterfall observed at the sites listed in Table 1 into the ORCHIDEE model, with the aim to describe more adequately the evergreen tropical forest phenology. Replacement of old by young leaves during periods of high productivity is hypothesized to be the driving mechanism of the observed litterfall seasonality. We test whether this process can enhance canopy photosynthetic capacity and increase the annual forest carbon gain in light-limiting conditions. Furthermore, it is tested whether the introduced seasonal variability in leaf properties leads to a better representation of GPP and latent heat (LE fluxes) in the ORCHIDEE model.

The results of this modification in the model parameterizations were evaluated in detail at the flux tower site in French Guiana (Bonal et al., 2008) in a forest with a short dry season (2-3 months) and the flux tower site in Tapajós (km 67) with a longer dry season (5 months). The effects of the leaf litterfall modification on leaf age distribution, photosynthetic capacity and leaf area index (hereinafter LAI) were quantified and cross-validated using leaf litterfall and eddy covariance LE and GPP measurements at both sites. Litterfall was validated with an additional long-term dataset from Panama. We tested whether by including the changed canopy dynamics a better representation of the seasonal fluxes and leaf litterfall patterns was obtained.

\section{Material and methods}

\subsection{Modelling strategy}

The modelling strategy was chosen after a first exploration of the relation between leaf litterfall data and meteorological data for the Guyaflux and Tapajós (km 67) sites. Good correspondences between measured leaf litterfall and estimates based on specific regressions of climate variables for both locations (data not shown) were found. However, by introducing such regressions in a global vegetation model, the site-specific empirical coefficients will not necessarily hold at a larger scale. Therefore, a seasonal leaf litterfall flux was introduced instead, assuming optimality in leaf turnover (Hikosaka, 2005) and self-thinning of leaves (White, 1981) with the effect of keeping leaf area index and leaf mass 


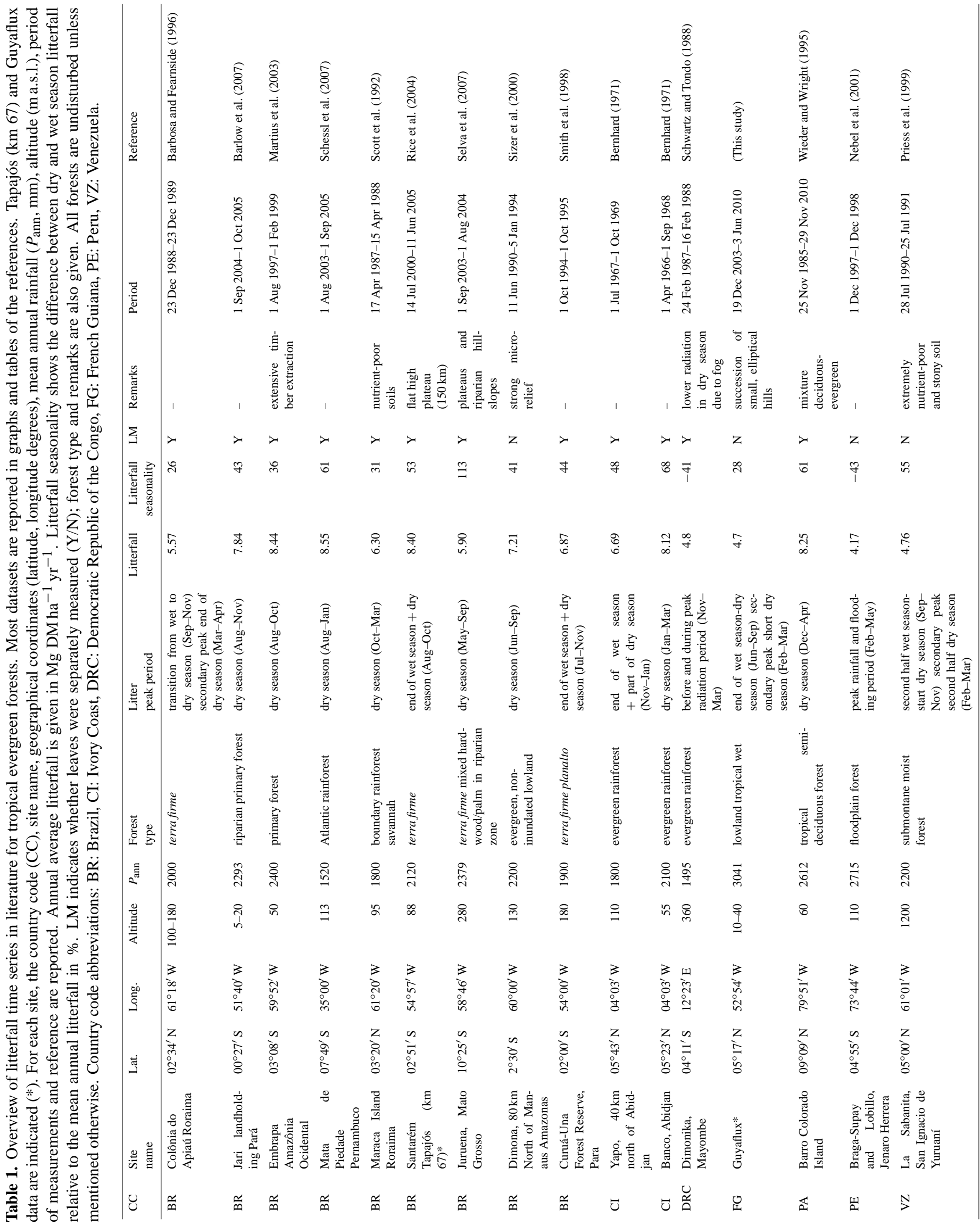


constant through time. Leaf turnover is hence seen as a mechanism for trees to enhance their light use by adapting photosynthetic capacity as a strategy to increase their chances of survival in the strong competition of the crowded forest. Leaf self-thinning is a consequence of the high density of leaves in the canopy of evergreen tropical forest stands and implies that, when a new leaf is produced, an older, less efficient, leaf will shed to prevent self shading and to sustain canopy photosynthesis. The parameterization of daily leaf litterfall in ORCHIDEE was modified by making the leaf litterfall proportional to the daily leaf net primary production $\left(\mathrm{NPP}_{\text {leaf }}\right)$ in such a way that the carbon flux lost through falling of the oldest leaves equals the carbon flux allocated to the youngest leaves (see Sects. 2.2.3 and 2.2.4).

The canopy leaf biomass is hence modelled to be at steady state, remaining constant at $391 \mathrm{~g} \mathrm{~m}^{-2}$ while leaf litterfall has seasonal changes introduced that result in seasonal changes in leaf age in ORCHIDEE. This is because leaf biomass is linked to a leaf age class bookkeeping model (see Sect. 2.2.3) that keeps track of the leaf age structure and that replaces older leaves by new, young ones, created from NPP leaf. Carbon is allocated to the youngest leaf age class first, and then ORCHIDEE leaf age is updated daily through leaf biomass conversion from one leaf age class into the next one. The seasonal changes in leaf age result in seasonal changes in photosynthetic capacity, because the value of the latter is parameterized as a function of leaf age in ORCHIDEE as explained in Sect. 2.2.1.

The idea behind the introduced seasonal variation in $V_{\mathrm{c}, \max }$ is that this is a strategy of the vegetation to maximize carbon gains with minimum costs and to facilitate the use of limiting resources, which is most likely light in tropical evergreen forest canopies (in addition to nutrients). The vegetation can enhance its light use by investing in fresh, more efficient leaves which, to prevent self-shading, require coincident loss of other, older and less efficient ones (Ackerly, 1999; Killingbeck and Whitford, 2001; Malhi et al., 2011). The increased light availability and resulting production in absence of other limitations at the beginning of and during the dry season hence drive an increased leaf turnover rate. Simultaneously, the vegetation is expected to adapt nutrient allocation to leaves in time to maximize photosynthesis and minimize respiration.

This analysis aims to understand how changing leaf age distribution drives seasonality in $V_{\mathrm{c}, \max }$ and how it impacts the resulting fluxes. It is possible to study the canopy seasonality of these ecosystems with different alternative hypotheses like seasonal changes in LAI or seasonal changes of specific leaf area (SLA). Nevertheless, the hypothesis here merely is focused on changes in $V_{c \text {,max }}$ seasonal variation, unaccompanied by changes in LAI. The hypothesis that seasonal GPP variations are driven by seasonal changes of $V_{\mathrm{c}, \max }$ only due to seasonal leaf turnover, with little or no associated changes in LAI, is also supported by field measurements of Brando et al. (2010) in Amazon and by De Wasseige et al. (2003) in central Africa.

Additional to the new leaf litterfall parameterization which drives phenology equations in the model by impacting the rejuvenation of leaves, two standard ORCHIDEE parameter values were modified for tropical evergreen forests based on field inventory estimates in Neotropical forests (Malhi et al., 2009a; Malhi et al., 2011). These two parameters are the fraction of carbon allocated to leaves and the temperature response of fine root maintenance respiration.

\subsection{ORCHIDEE model}

ORCHIDEE is a global process-based vegetation model (Krinner et al., 2005) that can be run in coupled mode as a part of the IPSL-CM5 Earth system model (Marti et al., 2010) and can be used to understand the interactions between the atmosphere and biosphere and study feedbacks between climate and vegetation cover change.

ORCHIDEE combines a surface-vegetation-atmosphere transfer scheme with explicit parameterizations of ecosystem carbon dynamics. The exchange of carbon, energy and water fluxes between the atmosphere and the land surface is calculated with a 30-min time step (Ducoudré et al., 1993). The carbon dynamics of ecosystems includes carbon allocation, respiration and seasonal phenological processes, of particular interest to this study.

ORCHIDEE distinguishes 13 plant functional types, or PFTs (Smith et al., 1997), varying from tropical to temperate or boreal forests, natural or agricultural $\mathrm{C} 3$ or $\mathrm{C} 4$ grasslands. PFT-specific parameter values (Sitch et al., 2003) and different prognostic phenology schemes can be attributed. The focus in this paper is on the phenology of PFT tropical broad-leaved evergreen (TrBE) forest, which, in the standard scheme, has no seasonal cycle in leaf litterfall included. In this study the standard ORCHIDEE version is indicated as ORCHIDEE STANDARD, while the modified model version is further referred to as ORCHIDEE-TrBE (ORCHIDEETropical Broad-leaved Evergreen trees) version.

\subsubsection{Photosynthesis formulation}

Canopy photosynthesis is calculated at the leaf scale following the Farquhar et al. (1980) model. The formulation of stomatal conductance follows Ball et al. (1987) where the assimilation rate is linearly related to the $\mathrm{CO}_{2}$ concentration gradient between atmosphere and the carbon fixation site inside the leaves. The coefficient of proportionality, or leaf conductance, is a function of relative air humidity $(\%)$, net assimilation rate and atmospheric $\mathrm{CO}_{2}$ concentration (Ball et al., 1987).

The maximum carboxylation capacity of photosynthesis $\left(V_{\mathrm{c}, \max }\right)$, further also called photosynthetic capacity, is parameterized as a function of leaf age. It increases from a low initial value at leaf flushing to a PFT-dependent, prescribed, 
optimum value after full leaf expansion, stays constant at this optimum until $50 \%$ of a critical leaf age value is reached, and then decreases to a lower value for the older leaves (Ishida et al., 1999). Figure 1 schematically shows how $V_{\mathrm{c}, \max }$ changes as a function of leaf age, with $65 \mu \mathrm{mol} \mathrm{CO} \mathrm{Cm}^{-2} \mathrm{~s}^{-1}$ the tropical evergreen optimum light-limited photosynthetic capacity (Krinner et al., 2005) for leaves at the top of the canopy. The relationship between $V_{c \text {,max }}$ and leaf age (Fig. 1) is supported by different studies (Ackerly and Bazzaz, 1995; Coste et al., 2009; Kitajima et al., 1997; Kitajima et al., 2002) that showed a decreasing photosynthetic capacity with leaf age for tropical species. Furthermore, the relation is supported by the findings of Steppe et al. (2011) and Chapin et al. (2002) that reported on decreasing photosynthetic capacity with leaf age due to modifications in leaf size, thickness, density, foliar nitrogen content and lignin content in species worldwide.

ORCHIDEE includes an exponential decrease of $V_{\mathrm{c} \text {, max }}$ with canopy depth according to the approach of Johnson and Thornley (1984) for the scaling of the different horizontal leaf layers to the entire canopy. There are four different leaf age classes assumed in the model set-up, and an age class weighed average value of $V_{\mathrm{c}, \max }$ is used to calculate the overall canopy photosynthesis.

\subsubsection{Net primary productivity and carbon allocation}

Net primary productivity (NPP), calculated as the difference between photosynthesis and autotrophic respiration, is attributed on a daily basis to five different biomass pools: leaves, fine roots, coarse roots, aboveground woody biomass and reproductive tissues (fruits and flowers). The fraction of carbon that is allocated daily to each carbon pool can be written as follows(Delbart et al., 2010):

$f_{\text {alloc,pool }}=\frac{\mathrm{NPP}_{\text {pool }}}{\mathrm{NPP}_{\text {tot }}}$

with NPP pool the amount of carbon attributed to the biomass pool and NPP tot the total NPP, the latter being calculated in ORCHIDEE as production minus autotrophic respiration:

$\mathrm{NPP}_{\text {tot }}=\mathrm{GPP}-\sum_{i=1}^{5} R_{\text {maint,pool }}-\sum_{i=1}^{5} R_{\text {growth, }_{\text {pool }}}$

with $R_{\text {maint,pool }_{i}}$ the maintenance respiration and $R_{\text {growth,pool }_{i}}$ the growth respiration of the biomass pool $i$.

The carbon allocation scheme in ORCHIDEE is based on environmentally coupled partitioning theory of the fractions of NPP allocated to the different compartments in function of the availability of light, nitrogen and water (Friedlingstein et al., 1999). Inspection of the ORCHIDEE outputs for the PFT tropical evergreen forest at several Amazon sites shows that the fraction allocated to each pool remains constant throughout the year, the leaf allocation factor $\left(f_{\text {alloc,leaf }}\right)$ being 0.27 , indicating that resources are never limiting the modelled allocation factors. Only when LAI exceeds the maximum value $\left(\mathrm{LAI}_{\max }\right)$, preset to 7 in ORCHIDEE, NPP is no longer allocated to leaves but to woody biomass aboveground instead.

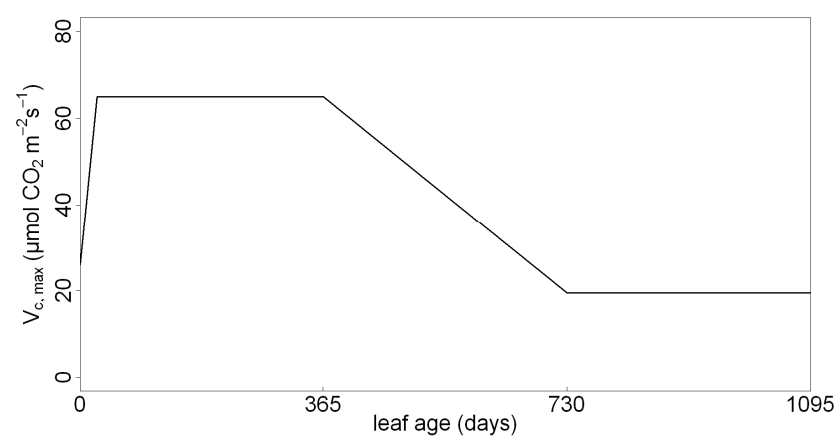

Fig. 1. In ORCHIDEE, leaf photosynthetic capacity $\left(V_{\mathrm{c}, \max }\right)$ is determined as a function of leaf age. The slope of the curve is determined by a critical leaf age parameter, which is set to 730 days for tropical evergreen forests.

In this study, the values of two parameters of the allocation scheme are modified for PFT TrBE. The first modified parameter value is $f_{\text {alloc,leaf }}$ which is slightly increased from 0.27 to 0.30 , supported by $\mathrm{NPP}_{\text {leaf }}$ estimates reported by Chave et al. (2008) for Nouragues in central French Guiana and by the findings of Malhi et al. (2011) for 35 sites in tropical evergreen forests worldwide. The latter reported a fraction of $0.41 \mathrm{NPP}_{\text {tot }}$ allocated to the entire canopy (leaves, flowers, fruits and fine twigs) that, assuming that the percentage of leaves is $73 \%$ (Malhi et al., 2011), results in an $f_{\text {alloc,leaf }}$ value of 0.3. In addition, Malhi et al. (2011) found low variances and small spatial differences in the fraction of $\mathrm{NPP}_{\text {tot }}$ allocated to the canopy in 35 tropical forest sites (linear fit with $\left.r^{2}=0.88, p<0.0001\right)$.

The second modification was made in the parameterisation of fine root maintenance respiration $R_{\text {maint,fineroots, }}$ which, by adapting its temperature response, was decreased and hence brought to be more close to field measurements (Malhi et al., 2009a). $R_{\text {maint,fineroots }}$ is calculated in ORCHIDEE as a function of temperature and biomass (Ruimy et al., 1996):

$R_{\text {maint,fineroots }}=C_{\text {maint,r }} B_{\text {fineroots }}$.

$B_{\text {fineroots }}$ is the fine root biomass and $C_{\text {maint,r }}$ is the maintenance respiration rate, assumed to increase linearly with root-zone temperature, as given by

$C_{\text {maint }, \mathrm{r}}=C_{0, \text { maint }, \mathrm{r}}\left(1+0.12 T_{\text {fineroots }}\right)$.

$C_{0, \text { maint,r }}$ is the base maintenance respiration rate defined at $0^{\circ} \mathrm{C}$ for fine roots, set to a value of $1.67 \times 10^{-3} \mathrm{~g} \mathrm{Cg} \mathrm{C}^{-1}$ day $^{-1}$ for all PFTs in the standard version of ORCHIDEE. The standard ORCHIDEE $R_{\text {maint,fineroots }}$ of $12.43 \pm 2.01 \mathrm{MgCha}^{-1} \mathrm{yr}^{-1}$ is twice as high as field measurements of fine root respiration $R_{\text {fineroots }}$, $5.57 \pm 1.85 \mathrm{MgC} \mathrm{ha}^{-1} \mathrm{yr}^{-1}$ at Manaus, Tapajós (km 67) and Caxiuanã (Malhi et al., 2009a). Hence, the 
value $R_{\text {maint,fineroots }}$ was decreased by adjusting the parameter value $C_{0 \text {,maint,r }}$ from $1.67 \times 10^{-3}$ to a value of $0.5 \times 10^{-3} \mathrm{~g} \mathrm{C} \mathrm{g} \mathrm{C}^{-1}$ day $^{-1}$ for PFT TrBE. The standard ORCHIDEE $R_{\text {maint,fineroots }}$ value is assumed to be valid for vegetation types worldwide, but Ruimy et al. (1996) however also report on observations that indicate a lower sensitivity to temperature of tropical plants than the temperate of the boreal species (Loveys et al., 2003), which supports the ad-

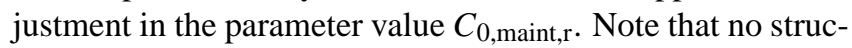
tural changes were made in the model formulation for carbon allocation, so that only the parameter values $f_{\text {alloc,leaf }}$ and $\mathrm{C}_{0, \text { maint,r }}$ for the TrBE PFT have been changed.

\subsubsection{Standard ORCHIDEE leaf litterfall}

The standard ORCHIDEE version (Krinner et al., 2005) assumes no seasonality in phenology for tropical evergreen forests, and describes daily leaf litterfall as a function of leaf age by:

$$
\Delta B_{\text {leaf }}=B_{\text {leaf }} \min \left(0.99, \frac{\Delta t}{A_{\text {crit }}}\left(\frac{A}{A_{\text {crit }}}\right)^{4}\right)
$$

with $\Delta B_{\text {leaf }}$ the daily amount of carbon lost by the canopy from leaf litterfall, $B_{\text {leaf }}$ the leaf biomass, and $\Delta t$ a daily time step. The leaf litterfall rate depends on leaf age $A$ and on the critical leaf age $A_{\text {crit }}$ parameter, which is set to a standard value of 730 days for tropical evergreen forest PFT. The formulation of Eq. (5) implies that young leaves hardly lose any biomass, while older leaves shed rapidly when they approach the critical leaf age $A_{\text {crit }}$.

Equation (5) is applied separately to each of four leaf age classes, each having a different leaf age $A$; the oldest leaf age class loses the largest amount of biomass and the youngest class loses the smallest amount. A leaf age class bookkeeping model keeps track of the leaf age structure and replaces older leaves by new, young ones that are created from $\mathrm{NPP}_{\text {leaf }}$ Carbon is allocated to the youngest leaf age class. Leaf ages by leaf biomass conversion from age class $i$ to age class $i+1$ according to

$$
\Delta B_{i \rightarrow i+1}=B_{i} \frac{\Delta t}{\tau}
$$

with $\tau$ being a time constant defined by $\tau=\frac{A_{\text {crit }}}{n}, n$ being the number of leaf age classes $(n=4)$. The total daily leaf litterfall is the weighed average sum of leaf turnover in each of the four leaf age classes.

Leaf age distribution among the four age classes is updated daily (as also shown in the canopy box of the scheme in Fig. 2), given the fraction of leaf biomass $f_{i, t}$ that enters in leaf age class $i$ on time $t$ is calculated by

$$
f_{i, t}=\frac{f_{i, t-1} B_{\text {leaf }, \mathrm{t}-1}+\Delta B_{i}}{B_{\text {leaf }, \mathrm{t}}}
$$

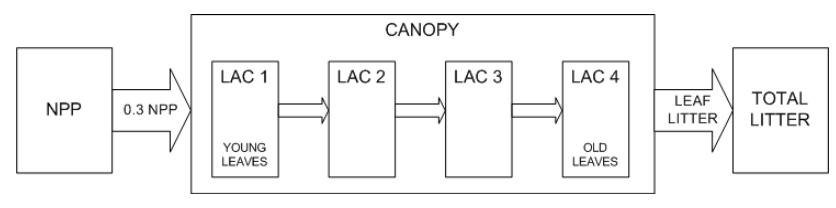

Fig. 2. Schematic representation of the new leaf turnover scheme implemented in ORCHIDEE-TrBE. The amount of carbon allocated to youngest leaves equals the amount of carbon lost by litterfall of oldest leaves. The canopy leaf biomass conversion of the four different leaf age classes (LAC) with biomass being passed from younger LAC to older LAC is as in the standard ORCHIDEE version.

$f_{i, t-1}$ is the fraction of leaf biomass in age class $i$ on time $t-$ 1 , and $B_{\text {leaf,t- } 1}$ is the total leaf biomass, sum of biomass over all age classes before the leaf age class distribution update. $\Delta B_{i}$ is the change in biomass due to aging in age class $i$, and $B_{\text {leaf,t }}$ is the new total leaf biomass summed over all age classes, after the leaf age class distribution update.

\subsubsection{Modification in the ORCHIDEE leaf litterfall parameterisation}

The standard parameterization of litterfall based on leaf age (Eq. 5) is replaced in this study by a leaf litter dynamics model (scheme shown in Fig. 2) where the daily leaf litterfall carbon amount ( $\left.\Delta B_{\text {leaf }}\right)$ is equalled to the carbon amount allocated daily to the leaves (NPPleaf):

$\Delta B_{\text {leaf }}=\mathrm{NPP}_{\text {leaf }} \quad$ if LAI $>6$.

This means that, as soon as the maximum LAI value is reached in the spin-up run, everyday exactly the same amount of carbon is lost by leaf litterfall as the amount of NPP allocated to the leaves (Sect. 2.3), resulting in a constant overall leaf biomass, yet with varying leaf age distribution throughout the season. According to Eq. (8), old leaves will be immediately replaced by young ones, or the canopy loses, for each amount of carbon of young leaf biomass formed, the same amount of carbon by shedding its oldest leaves. Hence, the leaf age distribution is altered through the conservation equation imposed by Eq. (8). Consequently, canopy photosynthetic capacity is changed since it is linked to leaf age (see Fig. 1).

Equation (8) also implies that the modelled pattern of leaf litterfall times with modelled NPP pattern and that the leaf turnover rate increases with increased $\mathrm{NPP}_{\text {leaf }}$. Hence, a seasonal pattern in leaf litterfall is introduced. As in the standard version of ORCHIDEE, the average daily leaf litterfall is calculated as the weighed average sum of leaves fallen in each of the four leaf age classes separately, and leaf age fractions are recalculated as in Eq. (7).

Note that the standard ORCHIDEE maximum LAI for tropical evergreen forest is $7.0 \mathrm{~m}^{2} \mathrm{~m}^{-2}$, while, in the new ORCHIDEE-TrBE version, the maximum LAI value is set to 
$6.0 \mathrm{~m}^{2} \mathrm{~m}^{-2}$ (Eq. 8). The LAI value of 6 is supported by field estimates from various authors that report different values for tropical evergreen forests. Malhado et al. (2009) reported an estimated mean LAI of $5.1 \mathrm{~m}^{2} \mathrm{~m}^{-2}$ measured across 50 experimental plots around the Tapajós (km 67) site. Juarez et al. (2008) report an average LAI of 5.5 to $6.0 \mathrm{~m}^{2} \mathrm{~m}^{-2}$ at the experimental site in Tapajós ( $\mathrm{km} 83)$. At Guyaflux, the mean plant area index (PAI, $\mathrm{m}^{2} \mathrm{~m}^{-2}$ ) of the inventory plots around the Guyaflux tower measured with a LI-COR LAI2000 is estimated at $7.0 \mathrm{~m}^{2} \mathrm{~m}^{-2}$ (Bonal et al., 2008), but PAI is higher than LAI because it includes the trunks and branches of the trees around the measurement points. Bonal et al. (2008) report that PAI did not differ between the wet and long dry period of 2005, and Malhado et al. (2009) could not detect significant seasonal variation in LAI measurements.

\subsection{Site descriptions}

The Guyaflux tower site $\left(5^{\circ} 16^{\prime} 54^{\prime \prime} \mathrm{N}, 52^{\circ} 54^{\prime} 44^{\prime \prime} \mathrm{W}\right)$ is located in French Guiana, South America, near Sinnamary, in an experimental unit that covers more than 400 ha of pristine, undisturbed wet tropical forest with about 140 tree species per ha (Gourlet-Fleury et al., 2004). Soils in the study area are mainly nutrient-poor acrisols (FAO-ISRIC-ISSS, 1998) with estimates of clay and sand content in the $1 \mathrm{~m}$ deep horizon of $43 \%$ and $48 \%$ on top of the hills and $26 \%$ and $65 \%$ on the sandy plateau (Bonal et al., 2008). There are two distinct rainy seasons: a moderate one from December to February and a stronger one from April to July. Of all sites reported in Table 1, Guyaflux has the highest mean annual rainfall (3041 mm). At Guyaflux, of the six years investigated, the lowest amount of rainfall fell in $2004(2756 \mathrm{~mm})$ and 2007 was the wettest year $(3550 \mathrm{~mm})$. Rainfall variability during the long dry season from September to November is high, ranging between $60 \mathrm{~mm}$ in 2005 to $306 \mathrm{~mm}$ in 2007 . Various meteorological variables like down-welling short-wave radiation $\left(\mathrm{SW}_{\text {down }} \mathrm{W} \mathrm{m}^{-2}\right)$, down-welling long-wave radiation $\left(\mathrm{LW}_{\text {down }}, \mathrm{W} \mathrm{m}^{-2}\right)$, air temperature $\left(T_{\mathrm{a}},{ }^{\circ} \mathrm{C}\right)$ and vapour pressure deficit (VPD, $\mathrm{kPa}$ ) at Guyaflux show seasonal variations linked to annual rainfall variability, mainly driven by the movement of the Inter-Tropical Convergence Zone. $\mathrm{SW}_{\text {down }}$ is about $30 \%$ higher in the dry months compared to the wet months. Figure 3 shows seasonal patterns in $\mathrm{SW}_{\text {down }}$, rainfall and the index of soil water content (ISWC). The latter is calculated based on soil water content measurements conducted every two to three weeks in tubes inserted down to $2.6 \mathrm{~m}$ depth in the soil and distributed along a $1 \mathrm{~km}$ transect (Bonal et al., 2008).

The Tapajós ( $\mathrm{km} 67)$ tower site ( $\left.2^{\circ} 51^{\prime} 24^{\prime \prime} \mathrm{S}, 54^{\circ} 57^{\prime} 32^{\prime \prime} \mathrm{W}\right)$ is located south of Santarém, Pará, Brazil, near the river Tapajós in an old growth moist Amazonian forest and described in detail by Saleska et al. (2003). Soils in the study area are mainly heavy Belterra clay ferralsols (FAO)/oxisols (USDA) interspersed with sandier patches and low organic matter content (Quesada et al., 2012). The soils in the

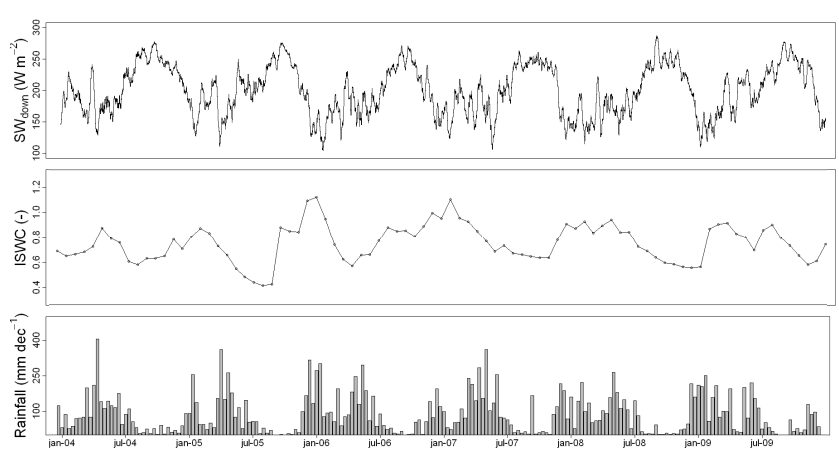

Fig. 3. Seasonal patterns in $\mathrm{SW}_{\text {down }}$, index of soil water content (ISWC) and rainfall at Guyaflux over 2004-2009 (data from Bonal et al., 2008 and from this study).

footprint of the tower contain approximately $68 \%$ clay or clay loam, $32 \%$ sand or sandy loam (Silver et al., 2000). The site is on a gently eastward sloping $(<1 \%)$ plateau that extends over $150 \mathrm{~km}$. Tapajós mean annual rainfall $(2120 \mathrm{~mm})$ is close to the mean of all sites reported in Table $1(2161 \mathrm{~mm})$. There is one distinct dry season $(<100 \mathrm{~mm}$ rainfall per month) that extends from July to November. The site shows signs of recovery from past disturbance that results in current high wood productivity over a wide area with biomass increments of $3.7 \mathrm{MgC} \mathrm{ha}^{-1} \mathrm{yr}^{-1}$ and possibly loss of soil carbon (Rice et al., 2004; Pyle et al., 2008).

The Barro Colorado Island (BCI) site $\left(9^{\circ} 09^{\prime} \mathrm{N}, 79^{\circ} 51^{\prime} \mathrm{W}\right)$ is located on a $15 \mathrm{~km}^{2}$ former hilltop located in the middle of the Panama Canal. Soils in the area are mainly clay-rich, yellow-brown oxisols that are $<50 \mathrm{~cm}$ thick. The island holds lowland tropical moist forest vegetation (Holdridge and Budowski, 1956) with both dry season deciduous and evergreen broadleaf species. About $12 \%$ of the tree species shed their leaves during the dry season (Croat, 1978) causing leaf litterfall to peak early in the dry season and to remain high throughout the dry season (Wieder and Wright, 1995). The dry season lasts approximately from mid-December to mid-April. Mean annual rainfall $(2600 \mathrm{~mm})$, of which $95 \%$ falls in the wet season, is typical for lowland moist tropical forest, close to the mean of all sites reported in Table 1 (2161 mm).

\subsection{Litterfall data}

Litterfall at the Guyaflux site was collected approximately every 20 days from December 2003 to December 2008 in 40 different traps distributed at the corners of 10 inventory plots located in the footprint of the Guyaflux tower, and for eight significantly representative traps (D. Bonal, personal communication, 2011) of these 40 from January 2009 to June 2010. Leaf litterfall was sorted from other litter components (twigs, fruits or flowers) during the year 2004 (Hättenschwiler et al., 2008). Average annual total litterfall is $4.7 \mathrm{Mg} \mathrm{ha}^{-1} \mathrm{yr}^{-1}$. Both total litterfall and leaf litterfall 
Table 2. Goodness of fit evaluation statistics for standard (STAND) and modified ORCHIDEE (TrBE) modelled leaf litterfall evaluated against field inventory leaf litterfall at Guyaflux $\left(2.40 \pm 1.38 \mathrm{MgCha}^{-1} \mathrm{yr}^{-1}\right)$, Tapajós (km 67) $\left(4.32 \pm 1.86 \mathrm{MgCha}^{-1} \mathrm{yr}^{-1}\right)$ and BCI $\left(4.25 \pm 1.95 \mathrm{MgC} \mathrm{ha}^{-1} \mathrm{yr}^{-1}\right)$.

\begin{tabular}{lrrrrrrrrr}
\hline & \multicolumn{2}{c}{ Mean } & & \multicolumn{2}{c}{ RMSE } & & \multicolumn{2}{c}{ Pearson's correlation } \\
\cline { 2 - 3 } \cline { 8 - 9 } & STAND & TrBE & & STAND & TrBE & & STAND & TrBE \\
\hline Guyaflux & 1.75 & 3.10 & & 1.23 & 1.07 & & -0.20 & 0.73 \\
Tapajós (km 67) & 1.78 & 2.91 & & 3.02 & 1.99 & & -0.27 & 0.61 \\
BCI, Panama & 1.86 & 3.38 & & 0.87 & 2.33 & & 0.01 & 0.42 \\
\hline
\end{tabular}

fraction show a peak at the beginning of the long and the short dry seasons. Leaf litter was estimated from total litterfall by extrapolating the litterfall fraction of 2004 for every year up to 2009 on the 8 traps dataset. This calculation resulted in an annual leaf litterfall of $2.4 \mathrm{Mg} \mathrm{Cha}^{-1} \mathrm{yr}^{-1}$ which is $33 \%$ smaller than the average of $3.2 \mathrm{MgC} \mathrm{ha}^{-1} \mathrm{yr}^{-1}$ from all sites reported in Table 1.

Litterfall at the Tapajós site was collected and sorted approximately every 14 days from July 2000 through June 2005 by Rice et al. (2004), and the dry matter contents of different litter types leaves, fruits and flowers, wood $(<2 \mathrm{~cm})$ and miscellaneous were reported. Assuming $50 \%$ carbon content, average annual leaf litterfall was $4.31 \mathrm{MgC} \mathrm{ha}^{-1} \mathrm{yr}^{-1}$. Leaf litterfall for this site showed distinct seasonal dynamics in 2002-2004 with peaks in the middle of the dry season of each consecutive year.

Litterfall at the BCI site was collected and sorted every week from November 1985 to present. Leaves were sorted from reproductive structures, fine wood and other fine litter like insect frass. Average annual leaf litterfall is 4.25 Mg C ha-1 $\mathrm{yr}^{-1}$ (assuming 50\% carbon content) showing distinct seasonal dynamics with peaks at the onset and throughout the dry season of each consecutive year.

\subsection{Eddy covariance data}

Eddy covariance and meteorological $30 \mathrm{~min}$ data (Bonal et al., 2008) have been recorded at the Guyaflux site since 2004 with sensors mounted $2 \mathrm{~m}$ above a $55 \mathrm{~m}$ high tower that was built in an existing, natural $100 \mathrm{~m}^{2}$ gap. The mean tree height at Guyaflux is $35 \mathrm{~m}$, with emergent trees exceeding $40 \mathrm{~m}$, and the measurements cover a range of more than $1 \mathrm{~km}$ of undisturbed forest in the direction of the prevailing winds. At the Tapajós (km 67) flux tower site, eddy covariance and meteorological $30 \mathrm{~min}$ data (Saleska et al., 2003) are recorded above the canopy on a 64-m-high tower. Mean canopy height is $40 \mathrm{~m}$ with emergent trees up to $55 \mathrm{~m}$.

The eddy flux data were processed following the Euro flux methodology described in Aubinet et al. (2000) using standard partitioning methodologies (Papale et al., 2006; Reichstein et al., 2005), where the threshold of friction velocity $(u *)$, below which nighttime NEE was correlated with $u *$, was applied. Negative GPP values during daytime were removed (e.g. in 2005 at the Guyaflux site, two large negative peaks, due to heavy rainfall events that strongly influenced overall GPP profile, were removed). For daily GPP means, only days with more than $80 \%$ of half hourly data available were retained.

\subsection{Model evaluation}

The leaf turnover mechanism imposed by Eq. (8) and the parameter value changes described in Sect. 2.4 were implemented simultaneously in ORCHIDEE-TrBE. The ORCHIDEE output, with and without the new phenology mechanism, is evaluated in detail with field measurements of leaf litterfall and eddy flux measurements from the Guyaflux site and the Tapajós site. For both flux tower sites, modelled $V_{\text {c,max }}$, leaf age and LAI patterns were examined. Additional validation against leaf litterfall data was performed at BCI in Panama.

At the flux tower sites, ORCHIDEE was forced with half hourly data of down-welling short-wave radiation $\mathrm{SW}_{\text {down }}\left(\mathrm{W} \mathrm{m}^{-2}\right)$, down-welling long-wave radiation $\mathrm{LW}_{\text {down }}\left(\mathrm{W} \mathrm{m}^{-2}\right)$, air temperature $T_{\mathrm{a}}(\mathrm{K})$, specific humidity $Q_{a}\left(\mathrm{~kg} \mathrm{~kg}^{-1}\right)$, wind speed $u\left(\mathrm{~m} \mathrm{~s}^{-1}\right)$, surface pressure $P_{\mathrm{s}}(\mathrm{Pa})$ and rainfall rate $P\left(\mathrm{~mm} \mathrm{~s}^{-1}\right)$ (Bonal et al., 2008; Saleska et al., 2003). At the BCI site, the run was forced by six hourly meteorological data of the ERA-Interim global atmospheric reanalysis of the European Centre for Medium-Range Weather Forecasts (ECWMF) (Berrisford et al., 2009). A spin-up run for all tree sites was performed for $230 \mathrm{yr}$ until all carbon reservoirs reached steady-state equilibrium and NEE levels, soil carbon pools and total $\mathrm{CO}_{2}$ fluxes were stabilized. The soil depth was set at $10 \mathrm{~m}$ and the root profile parameter $H_{\text {root }}$ at 0.1 according to Verbeeck et al. (2011), corresponding to a root distribution that decreases almost linearly with depth.

Standard and modified LE and GPP model outputs were evaluated against eddy covariance (EC) measurements to gauge model response to the modifications. GPP (daytime 08:00 h-16:00 h) and LE (daily 00:00 h-24:00 h) flux data were analyzed. The goodness of fit metrics, root-meansquare error (RMSE), index of agreement (IOA) (Legates and McCabe, 1999) and Pearson's correlation of the seasonal flux pattern of both GPP and LE and the GPP response to 

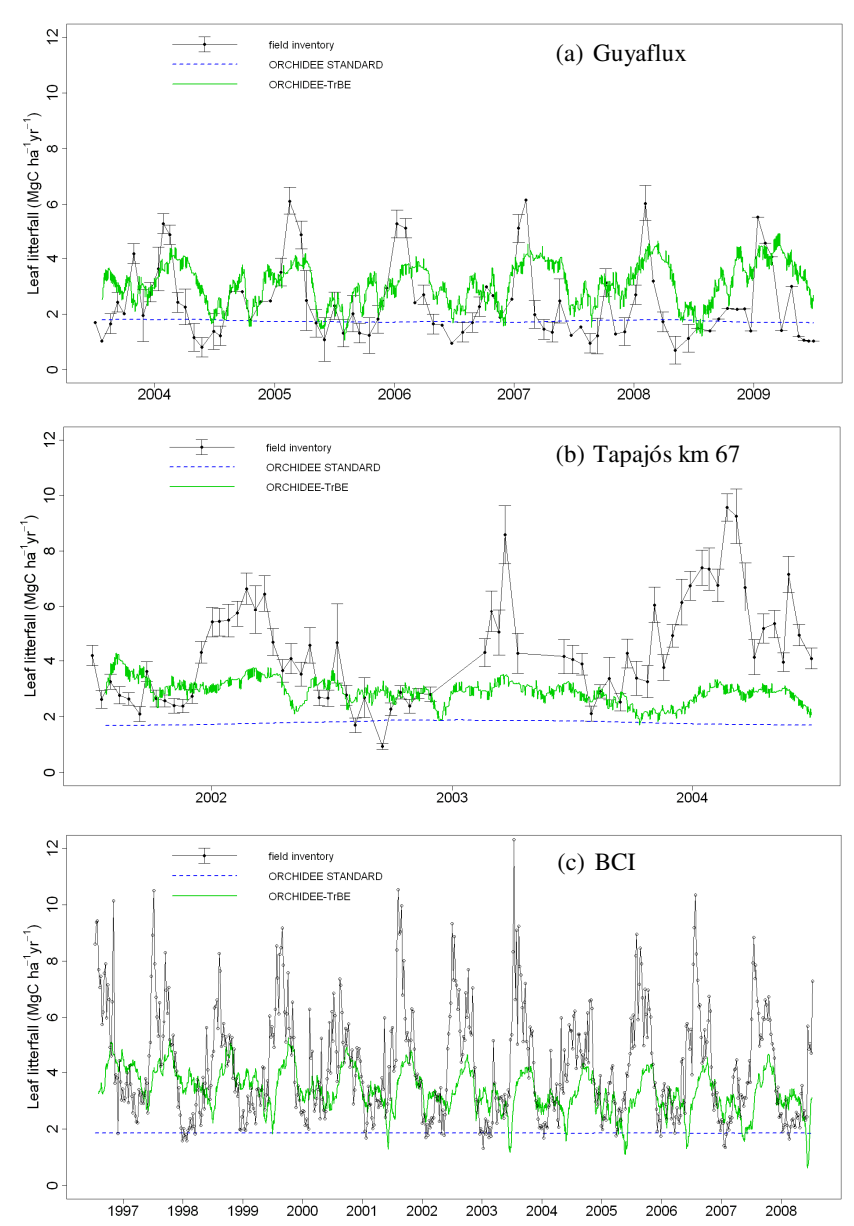

Fig. 4. Modelled and measured seasonal patterns of leaf litterfall $\left(\mathrm{MgC} \mathrm{ha}^{-1} \mathrm{yr}^{-1}\right)$. Field inventory measurements are compared with the standard model and the modified ORCHIDEE-TrBE leaf litterfall at (a) Guyaflux from 2004 to 2009 (b) Tapajós (km 67) from 2002 to 2004 (c) and Barro Colorado Island, Panama from 1997 to 2008 .

incoming radiation were analysed based on 10 daily running means.

\section{Results and discussion}

\subsection{Improved leaf litterfall seasonality}

The ORCHIDEE-TrBE resulting seasonal pattern in modelled leaf litter anticipates the peak in light availability seen in the long and short dry seasons and coincides with the timing of leaf litterfall of field inventory for BCI, Tapajós and Guyaflux (Fig. 4). For all three sites, the RMSE decreased compared to the standard version and the Pearson's correlation with observed litterfall increased, suggesting that an improved seasonal pattern was introduced by implementing a productivity ( $\left.\mathrm{NPP}_{\text {leaf }}\right)$ driven leaf litterfall. The summary statistics for the seasonal leaf litterfall pattern
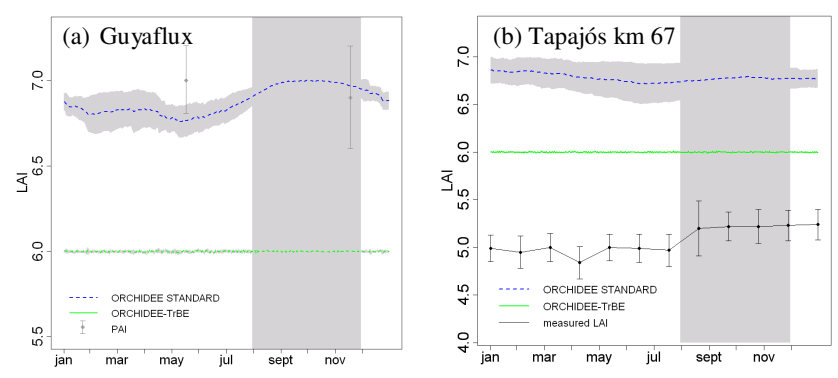

Fig. 5. LAI mean annual time profile plotted along with standard deviation (grey) at (a) Guyaflux 2004-2009 and (b) Tapajós (km 67) 2002-2004 for standard ORCHIDEE and ORCHIDEE-TrBE. The dry period $\left(<100 \mathrm{~mm} \mathrm{month}^{-1}\right)$ is shaded. For Guyaflux, field estimates of the mean plant area index (PAI, $\mathrm{m}^{2} \mathrm{~m}^{-2}$ ) made at $16-$ 18 May 2005 and 16-18 November 2005 based on 40 measurements within inventory plots around the flux tower using LAI2000 sensors (Bonal et al., 2008) are plotted. For Tapajós (km 67), mean seasonal variation from December 2003 to November 2004 measured using LAI-2000 Plant Canopy Analyser (Malhado et al., 2009) is plotted.

at Guyaflux, BCI and Tapajós (km 67) site are given in Table 2. With the new phenology, the modelled average annual leaf litterfall amount increases from $1.78 \pm 0.07$ to $2.91 \pm 0.42 \mathrm{MgCha}^{-1} \mathrm{yr}^{-1}$ at Tapajós ( $\mathrm{km} \mathrm{67),} \mathrm{from}$ $1.86 \pm 0.00$ to $3.38 \pm 0.75 \mathrm{MgCha}^{-1} \mathrm{yr}^{-1}$ at BCI and from $1.75 \pm 0.04$ to $3.10 \pm 0.75 \mathrm{MgC} \mathrm{ha}^{-1} \mathrm{yr}^{-1}$ at Guyaflux. The modified leaf litterfall at these three sites is similar to the $2.40 \pm 1.38 \mathrm{MgCha}^{-1} \mathrm{yr}^{-1}$ leaf litterfall field inventory at Guyaflux but lower than the inventory estimates of $4.25 \pm 1.94$ and $4.31 \pm 1.86 \mathrm{MgCha}^{-1} \mathrm{yr}^{-1}$ at BCI and Tapajós (km 67) respectively, but similar to the annual leaf litterfall of $3.2 \pm 1.03 \mathrm{Mg} \mathrm{Cha}^{-1} \mathrm{yr}^{-1}$ within uncertainties, averaged over all sites in Table 1 .

LAI is modelled to be constant at $6 \mathrm{~m}^{2} \mathrm{~m}^{-2}$, which is the predefined maximum value of the spin-up run. This value is lower than the mean LAI of $6.9 \mathrm{~m}^{2} \mathrm{~m}^{-2}$ in the standard version but more close to field inventory data ranging between 5.1 and 6 reported for the respective sites (Juaréz et al., 2008; Malhado et al., 2009). Instead of showing small seasonal changes, modelled LAI now remains constant due to the balanced leaf allocation and litterfall (Fig. 5). The standard version of the ORCHIDEE model would allocate NPP to woody aboveground biomass when a maximum LAI of $7.0 \mathrm{~m}^{2} \mathrm{~m}^{-2}$ is reached. With the new allocation, the leaf carbon is kept constant and the spillover mechanism to woody biomass carbon pool is no longer needed. The resulting aboveground wood production in ORCHIDEE-TrBE is $2.96 \pm 1.05$ for Guyaflux and $1.83 \pm 0.50 \mathrm{Mg} \mathrm{Cha}^{-1} \mathrm{yr}^{-1}$ for Tapajós ( $\mathrm{km} \mathrm{67),} \mathrm{which} \mathrm{is} \mathrm{on} \mathrm{the} \mathrm{order} \mathrm{of} \mathrm{magnitude} \mathrm{of}$ the field inventory estimate of $2.02 \pm 0.20 \mathrm{Mg} \mathrm{Cha}^{-1} \mathrm{yr}^{-1}$ in Caxiuanã (Almeida, unpublished data) and lower than the field estimate of $3.81 \pm 0.22 \mathrm{MgC} \mathrm{ha}^{-1} \mathrm{yr}^{-1}$ at Tapajós $(\mathrm{km}$ 67) (Rice et al., 2004). 

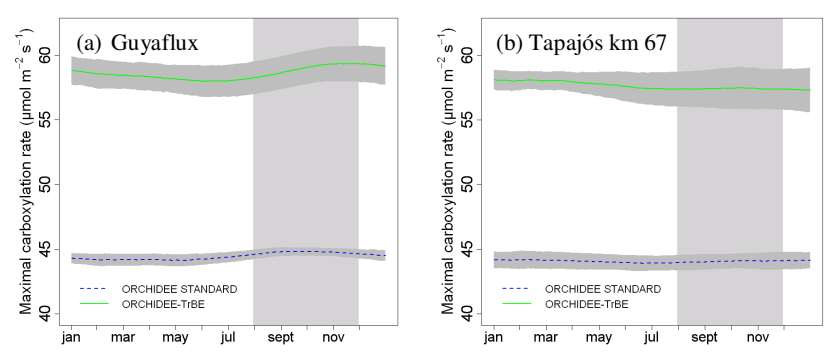

Fig. 6. $V_{c, \max }\left(\mu \mathrm{mol} \mathrm{CO} \mathrm{m}^{-2} \mathrm{~s}^{-1}\right)$ mean annual time profile plotted along with standard deviation (grey) at (a) Guyaflux 20042009 and (b) Tapajós (km 67) 2002-2004 standard ORCHIDEE and ORCHIDEE-TrBE. The dry period $\left(<100 \mathrm{~mm} \mathrm{month}^{-1}\right)$ is shaded.

\subsection{Impact on leaf age distribution and $V_{c, m a x}$ seasonality}

The leaf phenology parameterization keeps track of leaf age structure and replaces the old senescent leaves by new, young ones, created from primary production assimilates. By including seasonal leaf litterfall dynamics as in Eq. (8), the proportions of young and old leaves within a vegetation canopy change over seasons. At Guyaflux, increasing leaf litterfall in the dry season causes a more pronounced seasonal change in average leaf age ( 32 days younger in dry season than in wet season, compared to 19 days for the standard ORCHIDEE). Consequently, the mean leaf age decreases from $535 \pm 7$ to $324 \pm 16$ days. Leaf ages of 300 to 789 days for thirteen species in French Guiana were reported by Coste et al. (2011) for 2 to 4-yr-old seedlings in a greenhouse, while Reich et al. (2004) report leaf ages between 76 to 1693 days for adult Amazonian trees. The leaf age distribution and biomass by leaf age class for standard ORCHIDEE and ORCHIDEETrBE are shown in Fig. 6. Due to the modification, proportionally more young leaves are present, which is mainly achieved by a reduction of the biomass in the oldest leaf age class.

Younger leaves are assumed to have a higher photosynthetic capacity than older leaves in ORCHIDEE (Fig. 1). The combination of the decrease of $V_{\mathrm{c} \text {, max }}$ with leaf age and the new seasonal variation of the mean leaf age induces a seasonal cycle in canopy $V_{\mathrm{c}, \max }$ (Fig. 7), which is more pronounced for the Guyaflux site than for the Tapajós site. The leaf age decrease results in a $V_{\mathrm{c}, \max }$ increase at the top of canopy from 44 to $59 \mu \mathrm{mol} \mathrm{m}^{-2} \mathrm{~s}^{-1}$ and at the lower end of the canopy from 14 to $20 \mu \mathrm{mol} \mathrm{m}^{-2} \mathrm{~s}^{-1}$.

The canopy-integrated $V_{\mathrm{c}, \max }$ values (Johnson and Thornley, 1984) are $23 \mu \mathrm{mol} \mathrm{m}^{-2} \mathrm{~s}^{-1}$ for the standard ORCHIDEE, compared to $32 \mu \mathrm{mol} \mathrm{m}^{-2} \mathrm{~s}^{-1}$ for ORCHIDEE-TrBE. These integrated values depend on the vertical canopy profile that is assumed to be exponential for all PFTs in ORCHIDEE (Johnson and Thornley, 1984). However, the observed vertical leaf profiles of nitrogen through the canopy from a site in Amazon (Mercado et al., 2007) indicate a linear decrease
ORCHIDEE STANDARD
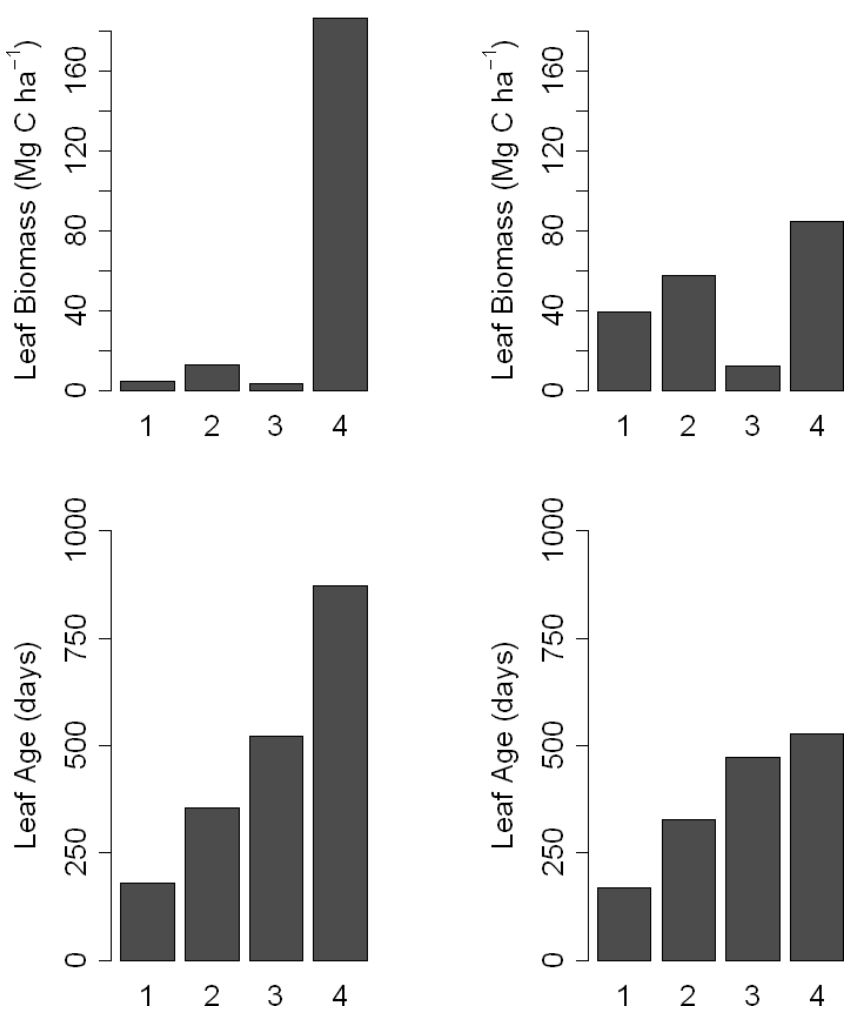

Fig. 7. Leaf biomass and leaf age distribution by leaf age class at Guyaflux for ORCHIDEE-STAND and ORCHIDEE-TrBE.

of $V_{\mathrm{c}, \max }$, less steep than that predicted by the exponential function implemented in ORCHIDEE. The study of the impact of a linear decrease in the vertical canopy $V_{c, \text { max }}$ profile was beyond the scope of this work, but should be tested in future studies.

Both standard and ORCHIDEE-TrBE modelled canopy $V_{\mathrm{c}, \max }$ fall within the wide range of values measured at the Tapajós (km 67) site from 10 (bottom canopy) to 106 (top canopy) $\mu \mathrm{mol} \mathrm{m}{ }^{-2} \mathrm{~s}^{-1}$ and fall within the range of values currently used in global vegetation models for tropical forests (43-82 $\mu \mathrm{mol} \mathrm{m}^{-2} \mathrm{~s}^{-1}$; Domingues et al., 2005). The canopyintegrated modelled $V_{\mathrm{c}, \max }$ value $\left(23\right.$ to $32 \mu \mathrm{mol} \mathrm{m}^{-2} \mathrm{~s}^{-1}$ ) is close to the value of $29 \mu \mathrm{mol} \mathrm{m}{ }^{-2} \mathrm{~s}^{-1}$ reported by Kattge et al. (2009) for oxisols, a tropical soil type that is very poor in nutrients. The annual pattern in Fig. 7 shows a more pronounced increase of $V_{\mathrm{c} \text {,max }}$ during the dry season compared to the wet season for ORCHIDEE-TrBE. Nevertheless, the introduced seasonality is modest, and corresponds to the $V_{\mathrm{c}, \max }$ seasonality that was inferred from eddy covariance measurements using an assimilation scheme with ORCHIDEE (Verbeeck et al., 2011). 

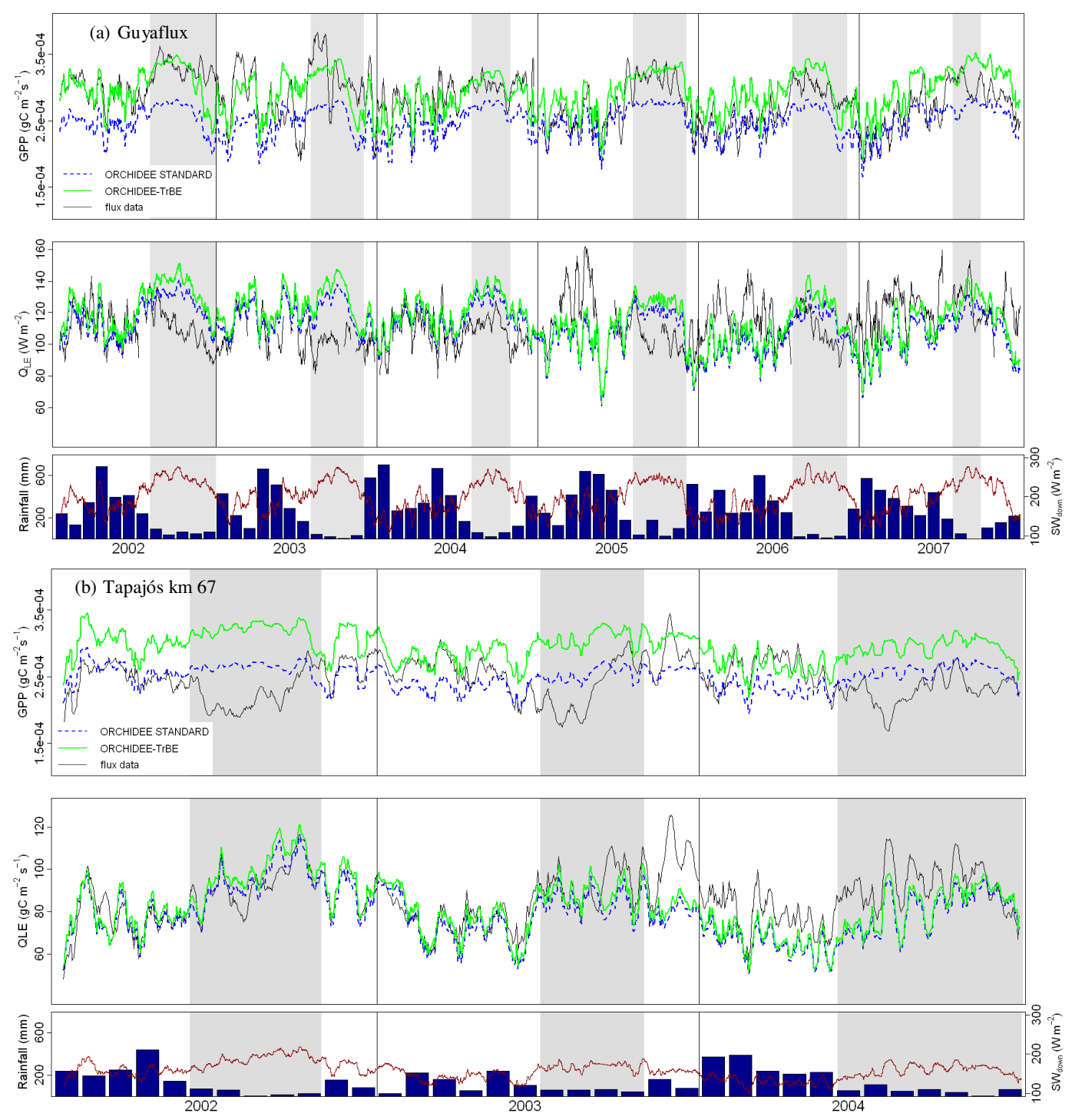

Fig. 8. Run-sequence 10-day moving averages at (a) Guyaflux and (b) Tapajós (km 67) including daytime data (08:00 h-16:00 h) of measured and modelled GPP and QLE 30 along with daily running mean shortwave downward radiation (SWdown) and monthly rainfall. Dry periods are shaded in grey $\left(<100 \mathrm{~mm} \mathrm{month}^{-1}\right)$.

\subsection{Impact on NPP}

The decreased (fine root) maintenance respiration in the modified model results in total NPP ( $\left.\mathrm{NPP}_{\text {tot }}\right)$ model outputs for Guyaflux that are closer to field estimates made at various Neotropical evergreen rainforest sites. Indeed, Guyaflux $\mathrm{NPP}_{\text {tot }}$ increased from $7.7 \pm 4.6 \mathrm{MgCha}^{-1} \mathrm{yr}^{-1}$ in the standard ORCHIDEE version to $10.5 \pm 7.0 \mathrm{MgCha}^{-1} \mathrm{yr}^{-1}$ in ORCHIDEE-TrBE, which is close to values reported by Malhi et al. (2009a) $(10.1 \pm 1.4, \quad 10.1 \pm 1.4$ and $10.1 \pm 1.4 \mathrm{MgCha}^{-1} \mathrm{yr}^{-1}$ for Manaus, Tapajós and Caxiuanã, respectively). Aragão et al. (2009) report an average $\mathrm{NPP}_{\text {tot }}$ of $12.8 \pm 1.3 \mathrm{Mg} \mathrm{Cha}^{-1} \mathrm{yr}^{-1}$ for 10 sites in Brazil, Peru and Colombia, and Malhi et al. (2011) report an estimate of $12.4 \pm 4.4 \mathrm{Mg} \mathrm{Cha}^{-1} \mathrm{yr}^{-1}$ for 35 tropical sites worldwide. Nevertheless, we should keep in mind that making field inventory estimates of $\mathrm{NPP}_{\text {tot }}$ is challenging. While the above-ground component (wood productivity) is relatively well studied and quantified, below-ground components are more difficult to quantify (Aragão et al., 2009).

\subsection{Impact on latent heat}

ORCHIDEE standard version was able to capture the seasonal patterns of latent heat both for Guyaflux and Tapajós (Figs. 8 and 9). The changes in the ORCHIDEE-TrBE model had only a minor impact on modelled latent heat. Therefore, the modelled latent heat fluxes stayed consistent with the measured data. At Guyaflux, the modelled LE corresponds 


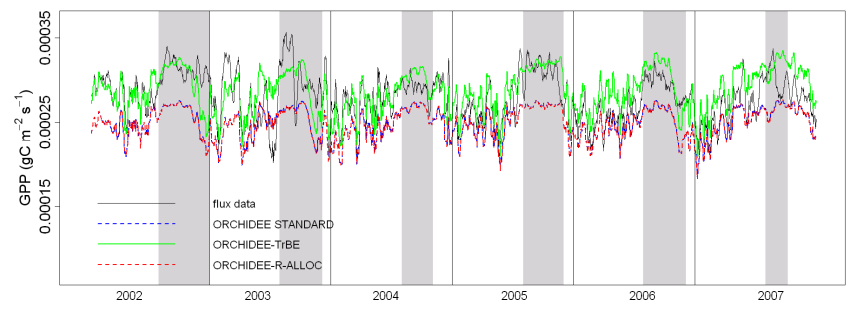

Fig. 9. A separate simulation where the standard version was adjusted only for allocation and respiration (+ORCHIDEE-RALLOC) shows that the altered GPP pattern is entirely due to seasonal changes in $V_{\mathrm{c} \text {,max }}$. Changing the respiration and allocation has no significant impact on GPP. Run-sequence 10-day moving averages at Guyaflux including daytime data (08:00 h-16:00 h) of measured and modelled GPP. Dry periods are shaded in grey $\left(<100 \mathrm{~mm} \mathrm{month}^{-1}\right)$.

well to the eddy flux-based estimates in the dry season and is slightly higher in the wet season. At this site, mean latent heat increased from $111 \pm 14 \mathrm{~W} \mathrm{~m}^{-2}$ to $117 \pm 17 \mathrm{~W} \mathrm{~m}^{-2}$ due to the modification. Both values are close to the annual mean of flux-derived GPP of $112 \pm 14 \mathrm{~W} \mathrm{~m}^{-2}$. At Tapajós ( $\mathrm{km} \mathrm{67),} \mathrm{mean} \mathrm{latent} \mathrm{heat} \mathrm{increased} \mathrm{marginally} \mathrm{from}$ $79 \pm 12 \mathrm{~W} \mathrm{~m}^{-2}$ to $83 \pm 13 \mathrm{~W} \mathrm{~m}^{-2}$; both values are close to the annual mean of flux-derived GPP $\left(87 \pm 13 \mathrm{~W} \mathrm{~m}^{-2}\right)$. Table 3 summarizes the evaluation statistics of seasonal latent heat patterns for Guyaflux and Tapajós.

\subsection{Impact on GPP}

At Guyaflux, the increased $V_{\mathrm{c}, \max }$ parameter value results in a GPP increase $\left(38 \pm 8 \mathrm{Mg} \mathrm{ha}^{-1} \mathrm{yr}^{-1}\right.$ versus $34 \pm 6 \mathrm{Mg} \mathrm{ha}^{-1} \mathrm{yr}^{-1}$ ) compared to the standard ORCHIDEE version, which is close to the annual mean of flux derived GPP (37 $\left.\pm 9 \mathrm{Mg} \mathrm{ha}^{-1} \mathrm{yr}^{-1}\right)$. Moreover, at Guyaflux the six years of eddy covariance measurements showed a higher GPP (mean of $3.03 \mathrm{~g} \mathrm{C} \mathrm{m}^{-2} \mathrm{~s}^{-1}$ ) in the dry season (June through December) than in the wet season (mean of $2.70 \mathrm{~g} \mathrm{C} \mathrm{m}^{-2} \mathrm{~s}^{-1}$ ). The ORCHIDEE-TrBE model better captures these dry and wet season variations (mean of $3.05 \mathrm{~g} \mathrm{C} \mathrm{m}^{-2} \mathrm{~s}^{-1}$ for dry season and $2.80 \mathrm{~g} \mathrm{C} \mathrm{m}^{-2} \mathrm{~s}^{-1}$ for wet season) than the standard version (mean of $2.58 \mathrm{~g} \mathrm{C} \mathrm{m}^{-2} \mathrm{~s}^{-1}$ for dry season and $2.43 \mathrm{~g} \mathrm{C} \mathrm{m}^{-2} \mathrm{~s}^{-1}$ for wet season). Both GPP model outputs showed an annual seasonal cycle with an increase during the dry season that follows the seasonal pattern in $\mathrm{SW}_{\text {down }}$ (Fig. 8). However, the more pronounced wet and dry season $V_{\mathrm{c}, \max }$ variation (Fig. 6) results in a more pronounced relative dry season GPP increase in ORCHIDEETrBE, compared to the standard version, $27 \%$ versus $23 \%$, a response that is closer to the relative wet and dry season GPP difference in flux data of $29 \%$ seen at Guyaflux. At this site, not only the average mean GPP value has improved with the modified model (higher $V_{\mathrm{c}, \max }$ value), but also the seasonality in GPP has changed - although not drastically
- with dry and wet season variations better captured due to more pronounced $V_{\mathrm{c}, \max }$ variations. The resulting GPP response is supported by the findings of Brando et al. (2010) that suggested that seasonal variation in leaf flushing and hence canopy $V_{\mathrm{c}, \max }$, are associated with variations in GPP, even when unaccompanied by associated changes in LAI.

Also at Tapajós, modelled seasonal variation did not change significantly due to the modification (18\% versus $16 \%$ ), while the flux data show a difference of about $34 \%$ between highest and lowest GPP measurements (Fig. 9). At Tapajós, there is no pronounced wet/dry season difference seen in the GPP flux data. The model correspondence to flux data improved due to the modification during the wet season, but the end of wet season, beginning of dry season decrease in GPP seen in the flux data does not correspond to either ORCHIDEE model outputs. It is therefore clear that the discrepancy between measured and ORCHIDEE modelled GPP at the Tapajós site during the dry season, which was already observed by Verbeeck et al. (2011), could not be resolved by adding litterfall dynamics only.

Table 3 summarizes the evaluation statistics of seasonal patterns of GPP for Guyaflux and Tapajós. Due to the modification, the Guyaflux new GPP model outputs were closer to the eddy correlation-based estimates of GPP. RMSE at that site decreased from $3.53 \times 10^{-5} \mathrm{~g} \mathrm{C} \mathrm{m}^{-2} \mathrm{~s}^{-1}$ to $2.46 \times 10^{-5} \mathrm{~g} \mathrm{C} \mathrm{m}^{-2} \mathrm{~s}^{-1}$, and the Pearson correlation increased from 0.64 to 0.66 and IOA from 0.63 to 0.78. Guyaflux wet season Pearson's correlation (0.62) for ORCHIDEE-TrBE GPP is higher than the dry season correlation (0.39), suggesting that the implementation in ORCHIDEE of some processes that typically occur in the dry season, possibly drought stress, still needs improvement. At Tapajós (km 67), the improved litterfall scheme was still not able to improve the fit to the observed seasonal GPP pattern.

A separate simulation was made where the standard version was adjusted only for allocation and respiration (named ORCHIDEE-AllocResp) to test the different impacts of the altered litter model and the adjusted allocation and respiration parameters (Fig. 9). The simulations show that changing the respiration and allocation has no significant impact on GPP and that the altered GPP pattern is entirely due to seasonal changes in $V_{\mathrm{c} \text {, max }}$. ORCHIDEE-TrBE leaf biomass ( $390 \mathrm{~g} \mathrm{C} \mathrm{m}^{-2}$ ) is lower than ORCHIDEE-AllocResp leaf biomass $\left(454 \mathrm{~g} \mathrm{C} \mathrm{m}^{-2}\right.$ ), but it is the increased $V_{\mathrm{c} \text {,max }}$ that results in higher GPP. Decreased respiration results in doubling of the fine root biomass (220 to $480 \mathrm{~g} \mathrm{C} \mathrm{m}^{-2}$ ).

\subsection{Impact on GPP response to light}

Light response curves were analyzed in detail for Guyaflux (Fig. 10). The Guyaflux wet and dry season response curves of GPP to $\mathrm{SW}_{\text {down }}$ for flux data and model outputs show a nearly linear increase with increasing $\mathrm{SW}_{\text {down }}$ until a value of approximately $500 \mathrm{~W} \mathrm{~m}^{-2}$, after which the curve flattens and GPP does not increase any further with increasing 
Table 3. Goodness of fit evaluation statistics for standard (STAND) and modified ORCHIDEE (TrBE) modelled gross primary production $(\mathrm{GPP})$ and latent heat $\left(Q_{\mathrm{LE}}\right)$ evaluated against flux tower data at Guyaflux and Tapajós (km 67).

\begin{tabular}{|c|c|c|c|c|c|c|c|}
\hline & & \multicolumn{2}{|c|}{ IOA } & \multicolumn{2}{|c|}{ Pearson's correlation } & \multicolumn{2}{|c|}{ RMSE } \\
\hline & & STAND & TrBE & STAND & $\operatorname{TrBE}$ & STAND & $\operatorname{TrBE}$ \\
\hline \multirow[t]{2}{*}{ Guyaflux } & GPP & 0.63 & 0.78 & 0.64 & 0.66 & $3.53 \times 10^{-5}$ & $2.46 \times 10^{-5}$ \\
\hline & $Q_{\mathrm{LE}}$ & 0.47 & 0.46 & 0.14 & 0.14 & 18 & 20 \\
\hline \multirow[t]{2}{*}{ Tapajós (km 67) } & GPP & 0.41 & 0.41 & 0.06 & 0.04 & $2.70 \times 10^{-5}$ & $4.97 \times 10^{-5}$ \\
\hline & $Q_{\mathrm{LE}}$ & 0.78 & 0.81 & 0.71 & 0.70 & 12 & 11 \\
\hline
\end{tabular}
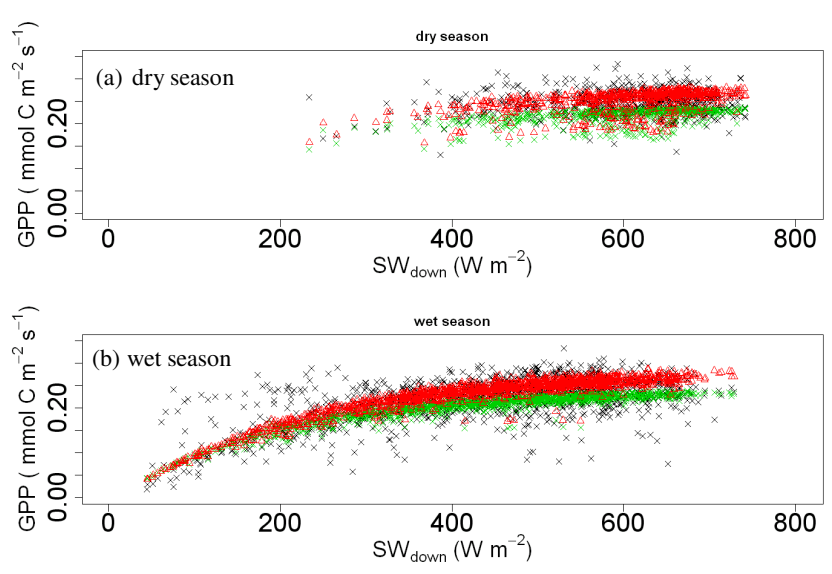

Fig. 10. The relationship at Guyaflux between GPP $\left(\mathrm{mmolC} \mathrm{m} \mathrm{C}^{-2} \mathrm{~s}^{-1}\right.$ ) flux tower data (black), ORCHIDEE model outputs from the standard version (green) and the modified ORCHIDEE-TrBE version (red) and $\mathrm{SW}_{\text {down }}\left(\mathrm{W} \mathrm{m}^{-2}\right)$ from 2004 until 2009. Models are plotted for dry season (a) and wet season (b) (threshold monthly rainfall $>100 \mathrm{~mm}$ ); daily means are calculated from daytime $(08: 00 \mathrm{~h}-16: 00 \mathrm{~h})$ data; hours with extreme rainfall $\left(>40 \mathrm{~mm} \mathrm{~h}^{-1}\right)$ were omitted.

light availability and a plateau $\mathrm{GPP}_{\max }$ is attained. At these high light levels, photosynthesis is limited by RuBisCO activity and $\mathrm{V}_{\mathrm{c} \text {, max }}$ determines the level of maximum photosynthesis that can be attained since there is a modelled linear relation between $V_{c, \max }$ and light saturation. The higher $V_{\text {c,max }}$ value in ORCHIDEE-TrBE version (Fig. 6) results in a higher $\mathrm{GPP}_{\max }$ plateau in the response curve compared to the plateau of the standard ORCHIDEE version.

\section{Conclusions}

The productivity-driven mechanism of seasonal leaf litterfall that was introduced in ORCHIDEE corresponds well with field inventory data for tropical forests and times with its seasonality. Although the new model simulates seasonal litterfall and leaf biomass dynamics in a more realistic way, the impacts on the simulated $V_{\mathrm{c} \text {,max }}$ patterns need to be explored more in the future. A thorough study of the relation between
$V_{\mathrm{c}, \max }$ and leaf age and the $V_{\mathrm{c}, \max }$ vertical canopy profile is recommended.

By including tropical forest leaf litterfall and a coincident leaf flush in ORCHIDEE, modelled GPP more accurately represents eddy correlation-based estimates at the Guyaflux site, suggesting that seasonal leaf litterfall is coupled to seasonal changes in productivity. At the Guyaflux site, in general, the fit to eddy correlation-based GPP flux estimates was improved and the results confirm that, at this site, by modifying canopy dynamics to benefit from increased production due to favourable light conditions, a better representation of the seasonal carbon flux patterns was made. Although the simulated latent heat fluxes were consistent with the data at both sites, the improved litterfall scheme was still not able to improve the fit to the observed seasonal GPP pattern at Tapajós, indicating that other factors than a seasonally varying $V_{\mathrm{c}, \max }$ might be driving the GPP response at this site. It would therefore be interesting to test other hypotheses in future work, like seasonal variations in SLA or LAI.

In this new version, carbon allocation to the leaves was increased and more closely fits to field inventory estimates for the Neotropics by lowering the maintenance respiration of fine roots and increasing the fraction of carbon allocated to leaves. The "overflow" mechanism of carbon to aboveground woody biomass when a maximum LAI is reached in the standard model is no longer needed; with the introduced modification, the leaf biomass remains constant. Future work can test the effect of the modification on aboveground woody biomass, possibly for the whole Amazon basin. LAI is now modelled to remain at a constant level; the canopy carbon content hence is at steady state with a constant leaf biomass, but leaf age and $V_{\mathrm{c} \text {,max }}$ dynamics are constantly changing, responding to seasonal changes in production, according to the available resources and light availability.

We are aware that the self thinning approach that we applied here to undisturbed forests might be less applicable to secondary or disturbed forests that have not yet grown the maximum leaf biomass or LAI that can be attained inside the canopy under the given circumstances at the site. Future work should therefore test our productivity-driven approach of modelling leaf litterfall for other tropical forest types, like secondary forests or perhaps flooded tropical forests. 
The analysis revealed a stronger dry season response of GPP to light compared to the wet season response and a higher sensitivity of GPP to changes in $V_{\mathrm{c}, \max }$ in the dry season compared to the wet season. In future work, we could also represent the true tropical evergreen canopy properties in more detail by including a spatial gradient in $V_{\mathrm{c}, \max }$, possibly based on leaf nitrogen content measurements, and see how it affects the carbon simulations.

Future analysis can be extended to other locations and different tropical forest types, not necessarily light limited, to see if we can reproduce the seasonal and also interannual variability in carbon uptake across the entire Amazon basin or the central African forests by including productivitydriven leaf turnover.

Acknowledgements. This research is financed by the Belgian Science Policy Office (Belspo) - Research Programme for EO, STEREO II, Contract SR/00/135. We are grateful to L. Hutyra, S. Saleska, and S. Wofsy for making the eddy flux and leaf litterfall data of the Tapajós km 67 site available at the Oak Ridge National Laboratory Distributed Active Archive Center. The authors would also like to thank Joseph Wright and Helene Muller-Landau for insightful comments and providing the leaf litter data at Barro Colorado Island.

Edited by: D. Lawrence

\section{References}

Ackerly, D.: Self-shading, carbon gain and leaf dynamics: A test of alternative optimality models, Oecologia, 119, 300-310, doi:10.1007/s004420050790, 1999.

Ackerly, D. D. and Bazzaz, F. A.: Plant growth and reproduction along co2 gradients: Non-linear responses and implications for community change, Glob. Change Biol., 1, 199-207, doi:10.1111/j.1365-2486.1995.tb00021.x, 1995.

Aragão, L. E. O. C., Malhi, Y., Metcalfe, D. B., Silva-Espejo, J. E., Jiménez, E., Navarrete, D., Almeida, S., Costa, A. C. L., Salinas, N., Phillips, O. L., Anderson, L. O., Alvarez, E., Baker, T. R., Goncalvez, P. H., Huamán-Ovalle, J., Mamani-Solórzano, M., Meir, P., Monteagudo, A., Patiño, S., Peñuela, M. C., Prieto, A., Quesada, C. A., Rozas-Dávila, A., Rudas, A., Silva Jr., J. A., and Vásquez, R.: Above- and below-ground net primary productivity across ten Amazonian forests on contrasting soils, Biogeosciences, 6, 2759-2778, doi:10.5194/bg-6-2759-2009, 2009.

Aubinet, M., Grelle, A., Ibrom, A., Rannik, U., Moncrieff, J., Foken, T., Kowalski, A. S., Martin, P., Berbigier, P., Bernhofer, C., Clement, R., Elbers, J., Granier, A., Grunwald, T., Morgenstern, K., Pilegaard, K., Rebmann, C., Snijders, W., Valentini, R., and Vesala, T.: Estimates of the annual net carbon and water exchange of forests: The Euroflux methodology, Adv. Ecol. Res., 30, 113-175, 2000.

Baker, I. T., Prihodko, L., Denning, A. S., Goulden, M., Miller, S., and da Rocha, H. R.: Seasonal drought stress in the amazon: Reconciling models and observations, J. Geophys. Res., 113, G00B01, doi:10.1029/2007jg000644, 2008.

Ball, J., Woodrow, T., and Berry, J.: A model predicting stomatal conductance and its contribution to the control of photosynthesis under different environmental conditions, Prog. Photosynthesis Res. Proc. Int. Congress 7th, Providence, 10-15 Aug 1986, Vol 4, Kluwer, Boston, 4, 221-224, 1987.

Barbosa, R. I., and Fearnside, P. M.: Carbon and nutrient flows in an amazonian forest: Fine litter production and composition at apiaú, roraima, brazil., Tropical Ecol., 37, 115-125, 1996.

Barlow, J., Gardner, T. A., Ferreira, L. V., and Peres, C. A.: Litter fall and decomposition in primary, secondary and plantation forests in the Brazilian Amazon, Forest Ecol. Manage., 247, 9197, 2007.

Beer, C., Reichstein, M., Tomelleri, E., Ciais, P., Jung, M., Carvalhais, N., Roedenbeck, C., Arain, M. A., Baldocchi, D., Bonan, G. B., Bondeau, A., Cescatti, A., Lasslop, G., Lindroth, A., Lomas, M., Luyssaert, S., Margolis, H., Oleson, K. W., Roupsard, O., Veenendaal, E., Viovy, N., Williams, C., Woodward, F. I., and Papale, D.: Terrestrial gross carbon dioxide uptake: Global distribution and covariation with climate, Science, 329, 834-838, doi:10.1126/science.1184984, 2010.

Berrisford, P., Dee, D., Fielding, K., Fuentes, M., Kallberg, P., Kobayashi, S. a., and Uppala, S.: The ERA-interim archive, ERA report series, 1. Technical report, European centre for mediumrange weather forecasts, Shinfield Park, Reading, 2009.

Bonal, D., Bosc, A., Ponton, S., Goret, J. Y., Burban, B., Gross, P., Bonnefond, J. M., Elbers, J., Longdoz, B., Epron, D., Guehl, J. M., and Granier, A.: Impact of severe dry season on net ecosystem exchange in the neotropical rainforest of french guiana, Glob. Change Biol., 14, 1917-1933, doi:10.1111/j.13652486.2008.01610.x, 2008.

Borchert, R.: Responses of tropical trees to rainfall seasonality and its long-term changes, Climatic Change, 39, 381-393, doi:10.1023/a:1005383020063, 1998.

Botta, A., Viovy, N., Ciais, P., Friedlingstein, P., and Monfray, P.: A global prognostic scheme of leaf onset using satellite data, Glob. Change Biol., 6, 709-725, 2000.

Bradley, A. V., Gerard, F. F., Barbier, N., Weedon, G. P., Anderson, L. O., Huntingford, C., Aragão, L. E. O. C., Zelazowski, P., and Arai, E.: Relationships between phenology, radiation and precipitation in the amazon region, Glob. Change Biol., 17, 2245-2260, doi:10.1111/j.1365-2486.2011.02405.x, 2011.

Brando, P. M., Goetz, S. J., Baccini, A., Nepstad, D. C., Beck, P. S. A., and Christman, M. C.: Seasonal and interannual variability of climate and vegetation indices across the amazon, Proc. Natl. Ac. Sci., 107, 14685-14690, doi:10.1073/pnas.0908741107, 2010.

Caldararu, S., Palmer, P. I., and Purves, D. W.: Inferring Amazon leaf demography from satellite observations of leaf area index, Biogeosciences, 9, 1389-1404, doi:10.5194/bg-9-13892012, 2012.

Chambers, J. Q. and Silver, W. L.: Some aspects of ecophysiological and biogeochemical responses of tropical forests to atmospheric change, Phil. Trans. Roy. Soc. London, 359, 463-476, doi:10.1098/rstb.2003.1424, 2004.

Chapin, S. F., Matson, P. A., and Vitousek, P. M.: Principles of terrestrial ecosystem ecology, Springer, New York, 490 pp., 2002.

Chave, J., Olivier, J., Bongers, F., Chatelet, P., Forget, P.-M., van der Meer, P., Norden, N., Riera, B., and Charles-Dominique, P.: Above-ground biomass and productivity in a rain forest of eastern south america, J. Tropic. Ecol., 24, 355-366, doi:10.1017/s0266467408005075, 2008. 
Chave, J., Navarrete, D., Almeida, S., Álvarez, E., Aragão, L. E. O. C., Bonal, D., Châtelet, P., Silva-Espejo, J. E., Goret, J.-Y., von Hildebrand, P., Jiménez, E., Patiño, S., Peñuela, M. C., Phillips, O. L., Stevenson, P., and Malhi, Y.: Regional and seasonal patterns of litterfall in tropical South America, Biogeosciences, 7, 43-55, doi:10.5194/bg-7-43-2010, 2010.

Coste, S., Roggy, J.-C., Garraud, L., Heuret, P., Nicolini, E., and Dreyer, E.: Does ontogeny modulate irradianceelicited plasticity of leaf traits in saplings of rain-forest tree species? A test with dicorynia guianensis and tachigali melinonii (fabaceae, caesalpinioideae), Ann. Forest Sci., 66, 709, doi:10.1051/forest/2009062, 2009.

Coste, S., Roggy, J.-C., Schimann, H., Epron, D., and Dreyer, E.: A cost benefit analysis of acclimation to low irradiance in tropical rainforest tree seedlings: Leaf life span and payback time for leaf deployment, J. Experiment. Botany, 62, 3941-3955, doi:10.1093/jxb/err092, 2011.

Cox, P. M., Betts, R. A., Jones, C. D., Spall, S. A., and Totterdell, I. J.: Acceleration of global warming due to carbon-cycle feedbacks in a coupled climate model, Nature, 408, 184-187, 2000.

Cox, P. M., Betts, R. A., Collins, M., Harris, P. P., Huntingford, C., and Jones, C. D.: Amazonian forest dieback under climatecarbon cycle projections for the 21st century, Theor. Appl. Climatol., 78, 137-156, doi:10.1007/s00704-004-0049-4, 2004.

Cramer, W., Bondeau, A., Schaphoff, S., Lucht, W., Smith, B., and Sitch, S.: Tropical forests and the global carbon cycle: Impacts of atmospheric carbon dioxide, climate change and rate of deforestation, Phil. Trans. Roy. Soc. London, 359, 331-343, doi:10.1098/rstb.2003.1428, 2004.

Croat, T. B.: Flora of barro colorado island, Stanford University Press, 1978.

de Wasseige, C., Bastin, D., and Defourny, P.: Seasonal variation of tropical forest LAI based on field measurements in Central African republic, Agr. Forest Meteorol., 119, 181-194, 2003.

Delbart, N., Ciais, P., Chave, J., Viovy, N., Malhi, Y., and Le Toan, T.: Mortality as a key driver of the spatial distribution of aboveground biomass in Amazonian forest: results from a dynamic vegetation model, Biogeosciences, 7, 3027-3039, doi:10.5194/bg-7-3027-2010, 2010.

Domingues, T. F., Berry, J. A., Martinelli, L. A., Ometto, J. P. H. B., and Ehleringer, J. R.: Parameterization of canopy structure and leaf-level gas exchange for an eastern amazonian tropical rain forest (tapajã3 s national forest, parã!, brazil), Earth Interactions, 9, 1-23, doi:10.1175/EI149.1, 2005.

Doughty, C. E. and Goulden, M. L.: Seasonal patterns of tropical forest leaf area index and co2 exchange, J. Geophys. Res., 113, G00B06, doi:10.1029/2007jg000590, 2008.

Ducoudré, I., N., Laval, K., and Perrier, A.: Sechiba : A new set of parameterizations of the hydrologic exchanges at the landatmosphere interface within the lmd atmospheric general circulation model, Am. Meteorol. Soc., Boston, MA, UK, 1993.

FAO/ISRIC/ISSS: World Reference Base for Soil Resources, World Soil Resources Report, 84. FAO, Rome, 88 pp., 1998.

Farquhar, G. D., Caemmerer, S., and Berry, J. A.: A biochemical model of photosynthetic $\mathrm{CO}_{2}$ assimilation in leaves of c-3 species, Planta, 149, 78-90, doi:10.1007/bf00386231, 1980.

Friedlingstein, P., Joel, G., Field, C. B., and Fung, I. Y.: Toward an allocation scheme for global terrestrial carbon models, Glob. Change Biol., 5, 755-770, 1999.
Gloor, M., Phillips, O. L., Lloyd, J. J., Lewis, S. L., Malhi, Y., Baker, T. R., López-Gonzalez, G., Peacock, J., Almeida, S., De Oliveira, A. C. A., Alvarez, E., Amaral, I., Arroyo, L., Aymard, G., Banki, O., Blanc, L., Bonal, D., Brando, P., Chao, K. J., Chave, J., DáVila, N., Erwin, T., Silva, J., Di Fiore, A., Feldpausch, T. R., Freitas, A., Herrera, R., Higuchi, N., Honorio, E., Jiménez, E., Killeen, T., Laurance, W., Mendoza, C., Monteagudo, A., Andrade, A., Neill, D., Nepstad, D., Vargas, P. N., Peñuela, M. C., Cruz, A. P., Prieto, A., Pitman, N., Quesada, C., Salomão, R., Silveira, M., Schwarz, M., Stropp, J., Ramírez, F., Ramrez, H., Rudas, A., Ter Steege, H., Silva, N., Torres, A., Terborgh, J., Vásquez, R., and Van Der Heijden, G.: Does the disturbance hypothesis explain the biomass increase in basin-wide amazon forest plot data?, Glob. Change Biol., 15, 2418-2430, doi:10.1111/j.1365-2486.2009.01891.x, 2009.

Golding, N., and Betts, R.: Fire risk in amazonia due to climate change in the hadcm 3 climate model: Potential interactions with deforestation, Global Biogeochem. Cy., 22, GB4007, doi:10.1029/2007gb003166, 2008.

Goulden, M. L., Miller, S. D., da Rocha, H. R., Menton, M. C., de Freitas, H. C., e Silva Figueira, A. M., and de Sousa, C. A. D.: Diel and seasonal patterns of tropical forest $\mathrm{Co}_{2}$ exchange, Ecol. Appl., 14, 42-54, doi:10.1890/02-6008, 2004.

Gourlet-Fleury, S., Guehl, J. M., and Laroussinie, O.: Ecology and management of a neotropical rainforest: Lessons drawn from paracou, a long-term experimental research site in french guiana, Elsevier, Paris, 311 pp., 2004.

Hättenschwiler, S., Aeschlimann, B., Coûteaux, M.-M., Roy, J., and Bonal, D.: High variation in foliage and leaf litter chemistry among 45 tree species of a neotropical rainforest community, New Phytologist, 179, 165-175, doi:10.1111/j.14698137.2008.02438.x, 2008.

Hikosaka, K.: Leaf canopy as a dynamic system: Ecophysiology and optimality in leaf turnover, Ann. Botany, 95, 521-533, doi:10.1093/aob/mci050, 2005.

Holdridge, L. R. and Budowski, G.: Report of an ecological survey of the republic of panama, Caribbean Forester, 17, 92-91, 1956.

Huete, A. R., Didan, K., Shimabukuro, Y. E., Ratana, P., Saleska, S. R., Hutyra, L. R., Yang, W., Nemani, R. R., and Myneni, R.: Amazon rainforests green-up with sunlight in dry season, Geophys. Res. Lett., 33, L06405, doi:10.1029/2005g1025583, 2006.

Ishida, A., Uemura, A., Koike, N., Matsumoto, Y., and Hoe, A. L.: Interactive effects of leaf age and self-shading on leaf structure, photosynthetic capacity and chlorophyll fluorescence in the rain forest tree, dryobalanops aromatica, Tree Physiol., 19, 741-747, 1999.

Johnson, I. R. and Thornley, J. H. M.: A model of instantaneous and daily canopy photosynthesis, J. Theor. Biol., 107, 531-545, doi:10.1016/s0022-5193(84)80131-9, 1984.

Juárez, R. I., da Rocha, H. R., Figueira, A. M. S., Goulden, M. L., and Miller, S. D.: An improved estimate of leaf area index based on the histogram analysis of hemispherical photographs, Agr. Forest Meteorol., 149, 920-928, 2009.

Kattge, J., Knorr, W., Raddatz, T., and Wirth, C.: Quantifying photosynthetic capacity and its relationship to leaf nitrogen content for global-scale terrestrial biosphere models, Glob. Change Biol., 15, 976-991, doi:10.1111/j.1365-2486.2008.01744.x, 2009.

Killingbeck, K. K. and Whitford, W. W.: Nutrient resorption in shrubs growing by design, and by default in chihuahuan desert 
arroyos, Oecologia, 128, 351-359, doi:10.1007/s004420100668, 2001.

Kitajima, K., Mulkey, S., and Wright, S.: Decline of photosynthetic capacity with leaf age in relation to leaf longevities for five tropical canopy tree species, Am. J. Botany, 84, 702-708, doi:10.2307/2445906, 1997.

Kitajima, K., Mulkey, S. S., Samaniego, M., and Joseph Wright, S.: Decline of photosynthetic capacity with leaf age and position in two tropical pioneer tree species, Am. J. Botany, 89, 1925-1932, doi:10.3732/ajb.89.12.1925, 2002.

Krinner, G., Viovy, N., de Noblet-Ducoudre, N., Ogee, J., Polcher, J., Friedlingstein, P., Ciais, P., Sitch, S., and Prentice, I. C.: A dynamic global vegetation model for studies of the coupled atmosphere-biosphere system, Global Biogeochem. Cy., 19, Gb1015, doi:10.1029/2003gb002199, 2005.

Legates, D. R. and McCabe, G. J.: Evaluating the use of "Goodness-of-fit" Measures in hydrologic and hydroclimatic model validation, Water Resour. Res., 35, 233-241, doi:10.1029/1998wr900018, 1999.

Lewis, S. L., Malhi, Y., and Phillips, O. L.: Fingerprinting the impacts of global change on tropical forests, Phil. Trans. Roy. Soc. London, 359, 437-462, doi:10.1098/rstb.2003.1432, 2004.

Lloyd, J. and Farquhar, G. D.: Effects of rising temperatures and [co2] on the physiology of tropical forest trees, Phil. Trans. Roy. Soc. London, 363, 1811-1817, doi:10.1098/rstb.2007.0032, 2008.

Loveys, B. R., Atkinson, L. J., Sherlock, D. J., Roberts, R. L., Fitter, A. H., and Atkin, O. K.: Thermal acclimation of leaf and root respiration: An investigation comparing inherently fast- and slow-growing plant species, Glob. Change Biol., 9, 895-910, doi:10.1046/j.1365-2486.2003.00611.x, 2003.

Luyssaert, S., Schulze, Detlef, E., Rner, Annett, Knohl, Alexander, Hessenmueller, Dominik, L., E., B., Cias, P., and Grace, J.: Oldgrowth forests as global carbon sinks, Nature Publishing Group, London, ROYAUME-UNI, 3 pp., 2008.

Maignan, F., Bréon, F.-M., Chevallier, F., Viovy, N., Ciais, P., Garrec, C., Trules, J., and Mancip, M.: Evaluation of a Global Vegetation Model using time series of satellite vegetation indices, Geosci. Model Dev., 4, 1103-1114, doi:10.5194/gmd-4-11032011, 2011.

Malhado, A. C. M., Costa, M. H., de Lima, F. Z., Portilho, K. C., and Figueiredo, D. N.: Seasonal leaf dynamics in an amazonian tropical forest, Forest Ecol. Manage., 258, 1161-1165, 2009.

Malhi, Y., Roberts, J. T., Betts, R. A., Killeen, T. J., Li, W., and Nobre, C. A.: Climate change, deforestation, and the fate of the amazon, Science, 319, 169-172, doi:10.1126/science.1146961, 2008.

Malhi, Y., Arag, O, L. E. O. C., Metcalfe, D. B., Paiva, R., Quesada, C. A., Almeida, S., Anderson, L., Brando, P., Chambers, J. Q., da Costa, A. C. L., Hutyra, L. R., Oliveira, P., Pati, O, S., Pyle, E. H., Robertson, A. L., and Teixeira, L. M.: Comprehensive assessment of carbon productivity, allocation and storage in three amazonian forests, Glob. Change Biol., 15, 1255-1274, 2009a.

Malhi, Y., Aragao, L., Galbraith, D., Huntingford, C., Fisher, R., Zelazowski, P., Sitch, S., McSweeney, C., and Meir, P.: Exploring the likelihood and mechanism of a climate-change-induced dieback of the amazon rainforest, Proc. Natl. Ac. Sci., 106, 20610-20615, 2009b.
Malhi, Y., Doughty, C., and Galbraith, D.: The allocation of ecosystem net primary productivity in tropical forests, Phil. Trans. Roy. Soc., 366, 3225-3245, doi:10.1098/rstb.2011.0062, 2011.

Martius, C., Hofer, H., Garcia, M. V. B., Rombke, J., and Hanagarth, W.: Litterfall, litter stocks and decomposition rates in rainforest and agroforestry sites in central amazonia, Nutrient Cyc. Agroecosyst., 68, 137-154, 2004.

Mercado, L. M., Huntingford, C., Gash, J. H. C., Cox, P. M., and Jogireddy, V.: Improving the representation of radiation interception and photosynthesis for climate model applications, Tellus B, 59, 553-565, 10.1111/j.1600-0889.2007.00256.x, 2007.

Myneni, R. B., Yang, W. Z., Nemani, R. R., Huete, A. R., Dickinson, R. E., Knyazikhin, Y., Didan, K., Fu, R., Juarez, R. I. N., Saatchi, S. S., Hashimoto, H., Ichii, K., Shabanov, N. V., Tan, B., Ratana, P., Privette, J. L., Morisette, J. T., Vermote, E. F., Roy, D. P., Wolfe, R. E., Friedl, M. A., Running, S. W., Votava, P., ElSaleous, N., Devadiga, S., Su, Y., and Salomonson, V. V.: Large seasonal swings in leaf area of amazon rainforests, Proc. Natl. Ac. Sci., 104, 4820-4823, doi:10.1073/pnas.0611338104, 2007.

Nebel, G., Dragsted, J., and Vega, A. S.: Litter fall, biomass and net primary production in flood plain forests in the peruvian amazon, Forest Ecol. Manage., 150, 93-102, 2001.

Nepstad, D. C., Moutinho, P., Dias-Filho, M. B., Davidson, E., Cardinot, G., Markewitz, D., Figueiredo, R., Vianna, N., Chambers, J., Ray, D., Guerreiros, J. B., Lefebvre, P., Sternberg, L., Moreira, M., Barros, L., Ishida, F. Y., Tohlver, I., Belk, E., Kalif, K., and Schwalbe, K.: The effects of partial throughfall exclusion on canopy processes, aboveground production, and biogeochemistry of an amazon forest, J. Geophys. Res., 107, 8085, doi:10.1029/2001jd000360, 2002.

Pan, Y., Birdsey, R. A., Fang, J., Houghton, R., Kauppi, P. E., Kurz, W. A., Phillips, O. L., Shvidenko, A., Lewis, S. L., Canadell, J. G., Ciais, P., Jackson, R. B., Pacala, S. W., McGuire, A. D., Piao, S., Rautiainen, A., Sitch, S., and Hayes, D.: A large and persistent carbon sink in the world's forests, Science, 333, 988993, doi:10.1126/science.1201609, 2011.

Papale, D., Reichstein, M., Aubinet, M., Canfora, E., Bernhofer, C., Kutsch, W., Longdoz, B., Rambal, S., Valentini, R., Vesala, T., and Yakir, D.: Towards a standardized processing of Net Ecosystem Exchange measured with eddy covariance technique: algorithms and uncertainty estimation, Biogeosciences, 3, 571-583, doi:10.5194/bg-3-571-2006, 2006.

Phillips, O. L., Malhi, Y., Higuchi, N., Laurance, W. F., Nuñez, P. V., Vásquez, R. M., Laurance, S. G., Ferreira, L. V., Stern, M., Brown, S., and Grace, J.: Changes in the carbon balance of tropical forests: Evidence from long-term plots, Science, 282, 439-442, doi:10.1126/science.282.5388.439, 1998.

Phillips, O. L., Aragao, L. E. O. C., Lewis, S. L., Fisher, J. B., Lloyd, J., Lopez-Gonzalez, G., Malhi, Y., Monteagudo, A., Peacock, J., Quesada, C. A., van der Heijden, G., Almeida, S., Amaral, I., Arroyo, L., Aymard, G., Baker, T. R., Banki, O., Blanc, L., Bonal, D., Brando, P., Chave, J., Alves de Oliveira, A. C., Cardozo, N. D., Czimczik, C. I., Feldpausch, T. R., Freitas, M. A., Gloor, E., Higuchi, N., Jimenez, E., Lloyd, G., Meir, P., Mendoza, C., Morel, A., Neill, D. A., Nepstad, D., Patino, S., Cristina Penuela, M., Prieto, A., Ramirez, F., Schwarz, M., Silva, J., Silveira, M., Thomas, A. S., ter Steege, H., Stropp, J., Vasquez, R., Zelazowski, P., Alvarez Davila, E., Andelman, S., Andrade, A., Chao, K.-J., Erwin, T., Di Fiore, A., Honorio C, E., Keeling, 
H., Killeen, T. J., Laurance, W. F., Pena Cruz, A., Pitman, N. C. A., Nunez Vargas, P., Ramirez-Angulo, H., Rudas, A., Salamao, R., Silva, N., Terborgh, J., and Torres-Lezama, A.: Drought sensitivity of the amazon rainforest, Science, 323, 1344-1347, 10.1126/science.1164033, 2009.

Poulter, B., Heyder, U., and Cramer, W.: Modeling the sensitivity of the seasonal cycle of gpp to dynamic lai and soil depths in tropical rainforests, Ecosystems, 12, 517-533, doi:10.1007/s10021009-9238-4, 2009.

Poulter, B., Hattermann, F., Hawkins, E. D., Zaehle, S., Sitch, S., Restrepo-Coupe, N., Heyder, U., and Cramer, W.: Robust dynamics of amazon dieback to climate change with perturbed ecosystem model parameters, Glob. Change Biol., 16, 24762495, doi:10.1111/j.1365-2486.2009.02157.x, 2010.

Prentice, I. C. and Lloyd, J.: C-quest in the amazon basin, Nature, 396, 619-620, doi:10.1038/25224, 1998.

Priess, J., Then, C., and Fölster, H.: Litter and fine-root production in three types of tropical premontane rain forest in South-East Venezuela, Plant Ecol., 143, 171-187, doi:10.1023/a:1009844226078, 1999.

Pyle, E. H., Santoni, G. W., Nascimento, H. E. M., Hutyra, L. R., Vieira, S., Curran, D. J., van Haren, J., Saleska, S. R., Chow, V. Y., Carmago, P. B., Laurance, W. F., and Wofsy, S. C.: Dynamics of carbon, biomass, and structure in two amazonian forests, J. Geophys. Res.-Biogeosci., 113, G00b08, doi:10.1029/2007jg000592, 2008.

Quesada, C. A., Phillips, O. L., Schwarz, M., Czimczik, C. I., Baker, T. R., Patiño, S., Fyllas, N. M., Hodnett, M. G., Herrera, R., Almeida, S., Alvarez D'avila, E., Arneth, A., Arroyo, L., Chao, K. J., Dezzeo, N., Erwin, T., di Fiore, A., Higuchi, N., Honorio Coronado, E., Jimenez, E. M., Killeen, T., Lezama, A. T., Lloyd, G., López-González, G., Luizão, F. J., Malhi, Y., Monteagudo, A., Neill, D. A., Núñez Vargas, P., Paiva, R., Peacock, J., Peñuela, M. C., Peña Cruz, A., Pitman, N., Priante Filho, N., Prieto, A., Ramírez, H., Rudas, A., Salomão, R., Santos, A. J. B., Schmerler, J., Silva, N., Silveira, M., Vásquez, R., Vieira, I., Terborgh, J., and Lloyd, J.: Basin-wide variations in Amazon forest structure and function are mediated by both soils and climate, Biogeosciences, 9, 2203-2246, doi:10.5194/bg-9-22032012, 2012.

Reich, P. B., Uhl, C., Walters, M. B., Prugh, L., and Ellsworth, D. S.: Leaf demography and phenology in amazonian rain forest: A census of 40000 leaves of 23 tree species, Ecol. Monogr., 74, 3-23, doi:10.1890/02-4047, 2004.

Reichstein, M., Falge, E., Baldocchi, D., Papale, D., Aubinet, M., Berbigier, P., Bernhofer, C., Buchmann, N., Gilmanov, T., Granier, A., Grünwald, T., Havránková, K., Ilvesniemi, H., Janous, D., Knohl, A., Laurila, T., Lohila, A., Loustau, D., Matteucci, G., Meyers, T., Miglietta, F., Ourcival, J.-M., Pumpanen, J., Rambal, S., Rotenberg, E., Sanz, M., Tenhunen, J., Seufert, G., Vaccari, F., Vesala, T., Yakir, D., and Valentini, R.: On the separation of net ecosystem exchange into assimilation and ecosystem respiration: Review and improved algorithm, Glob. Change Biol., 11, 1424-1439, doi:10.1111/j.13652486.2005.001002.x, 2005.

Rice, A. H., Pyle, E. H., Saleska, S. R., Hutyra, L., Palace, M., Keller, M., de Camargo, P. B., Portilho, K., Marques, D. F., and Wofsy, S. C.: Carbon balance and vegetation dynamics in an old-growth amazonian forest, Ecol. Appl., 14, 55-71, doi:10.1890/02-6006, 2004.

Ruimy, A., Dedieu, G., and Saugier, B.: Turc: A diagnostic model of continental gross primary productivity and net primary productivity, Global Biogeochem. Cy., 10, 269-285, doi:10.1029/96gb00349, 1996.

Saleska, S. R., Miller, S. D., Matross, D. M., Goulden, M. L., Wofsy, S. C., da Rocha, H. R., de Camargo, P. B., Crill, P., Daube, B. C., de Freitas, H. C., Hutyra, L., Keller, M., Kirchhoff, V., Menton, M., Munger, J. W., Pyle, E. H., Rice, A. H., and Silva, H.: Carbon in amazon forests: Unexpected seasonal fluxes and disturbance-induced losses, Science, 302, 1554-1557, 2003.

Samanta, A., Ganguly, S., Hashimoto, H., Devadiga, S., Vermote, E., Knyazikhin, Y., Nemani, R. R., and Myneni, R. B.: Amazon forests did not green-up during the 2005 drought, Geophys. Res. Lett., 37, L05401, doi:10.1029/2009g1042154, $2010 \mathrm{a}$.

Samanta, A., Ganguly, S., and Myneni, R. B.: Modis enhanced vegetation index data do not show greening of amazon forests during the 2005 drought, New Phytologist, 189, 11-15, doi:10.1111/j.1469-8137.2010.03516.x, 2010b.

Schwartz, D. and Tondo, F.: La production de litière en forêt dense équatoriale: Bilan d'un an de collecte à dimonika (mayombé, congo), ORSTOM Fonds Documentaire, Centre De PointeNoire, 15 pp., 1988.

Scott, D. A., Proctor, J., and Thompson, J.: Ecological studies on a lowland evergreen rainforest on Maraca Island, Roraima, Brazilm 2. Litter and nutrient cycling, J. Ecol., 80, 705-717, 1992.

Selva, E. C., Couto, E. G., Johnson, M. S., and Lehmann, J.: Litterfall production and fluvial export in headwater catchments of the Southern Amazon, J. Tropical Ecol., 23, 329-335, doi:10.1017/s0266467406003956, 2007.

Silver, W. L., Neff, J., McGroddy, M., Veldkamp, E., Keller, M., and Cosme, R.: Effects of soil texture on belowground carbon and nutrient storage in a lowland amazonian forest ecosystem, Ecosystems, 3, 193-209, doi:10.1007/s100210000019, 2000.

Sitch, S., Smith, B., Prentice, I. C., Arneth, A., Bondeau, A., Cramer, W., Kaplan, J. O., Levis, S., Lucht, W., Sykes, M. T., Thonicke, K., and Venevsky, S.: Evaluation of ecosystem dynamics, plant geography and terrestrial carbon cycling in the lpj dynamic global vegetation model, Glob. Change Biol., 9, 161$185,2003$.

Sizer, N. C., Tanner, E. V. J., and Ferraz, I. D. K.: Edge effects on litterfall mass and nutrient concentrations in forest fragments in central amazonia, J. Tropical Ecol., 16, 853-863, 2000.

Smith, T. M., Shugart, H. H., and Woodward, F. I.: Plant functional types: Their relevance to ecosystem properties and global change, International geosphere-biosphere programme book series 1, Cambridge University Press, Cambridge etc., 1997.

Stephens, B. B., Gurney, K. R., Tans, P. P., Sweeney, C., Peters, W., Bruhwiler, L., Ciais, P., Ramonet, M., Bousquet, P., Nakazawa, T., Aoki, S., Machida, T., Inoue, G., Vinnichenko, N., Lloyd, J., Jordan, A., Heimann, M., Shibistova, O., Langenfelds, R. L., Steele, L. P., Francey, R. J., and Denning, A. S.: Weak northern and strong tropical land carbon uptake from vertical profiles of atmospheric co2, Science, 316, 1732-1735, doi:10.1126/science.1137004, 2007.

Steppe, K., Niinemets, Ü., Teskey, R. O., Meinzer, F. C. C., Lachenbruch, B., and Dawson, T. E. E.: Tree size- and age-related 
changes in leaf physiology and their influence on carbon gain size- and age-related changes in tree structure and function, edited by: Meinzer, F. C., and Niinemets, Ã., Tree physiology, Springer Netherlands, 235-253, 2011.

Tian, H., Melillo, J. M., Kicklighter, D. W., McGuire, A. D., Helfrich, J. V. K., Moore, B., and Vorosmarty, C. J.: Effect of interannual climate variability on carbon storage in amazonian ecosystems, Nature, 396, 664-667, 1998.

Verbeeck, H., Peylin, P., Bacour, C., Bonal, D., Steppe, K., and Ciais, P.: Seasonal patterns of co2 fluxes in amazon forests: Fusion of eddy covariance data and the orchidee model, J. Geophys. Res., 116, G02018, doi:10.1029/2010jg001544, 2011.

White, J.: The allometric interpretation of the self-thinning rule, J. Theor. Biol., 89, 475-500, doi:10.1016/0022-5193(81)90363-5, 1981.
Wieder, R. K. and Wright, S. J.: Tropical forest litter dynamics and dry season irrigation on barro colorado island, panama, Ecology, 76, 1971-1979, 1995.

Wright, S. J. and Cornejo, F. H.: Seasonal drought and leaf fall in a tropical forest, Ecology, 71, 1165-1175, doi:10.2307/1937384, 1990.

Xiao, X., Zhang, Q., Saleska, S., Hutyra, L., De Camargo, P., Wofsy, S., Frolking, S., Boles, S., Keller, M., and Moore Iii, B.: Satellite-based modeling of gross primary production in a seasonally moist tropical evergreen forest, Remote Sens. Environ., 94, 105-122, 2005. 